\title{
Cardiac Channelopathies and Sudden Death: Recent Clinical and Genetic Advances
}

\author{
Anna Fernández-Falgueras ${ }^{1}$, Georgia Sarquella-Brugada ${ }^{2}$, Josep Brugada ${ }^{2}$, Ramon Brugada 1,3,4 \\ and Oscar Campuzano ${ }^{1,3, *}$ \\ 1 Cardiovascular Genetics Center, IDIBGI, Girona 17190, Spain; afernandez@gencardio.com (A.F.-F.); \\ ramon@brugada.org (R.B.) \\ 2 Arrhythmias Unit, Hospital Sant Joan de Déu, University of Barcelona, Barcelona 08950, Spain; \\ georgia@brugada.org (G.S.-B.); jbrugada@clinic.ub.es (J.B.) \\ 3 Medical Sciences Department, School of Medicine, University of Girona, Girona 17071, Spain \\ 4 Familial Cardiomyopathies Unit, Hospital Josep Trueta, Girona 17007, Spain \\ * Correspondence: oscar@brugada.org; Tel.: +34-87-298-7087 \\ Academic Editors: Fabio Franciolini and Luigi Catacuzzeno \\ Received: 22 November 2016; Accepted: 20 January 2017; Published: 29 January 2017
}

\begin{abstract}
Sudden cardiac death poses a unique challenge to clinicians because it may be the only symptom of an inherited heart condition. Indeed, inherited heart diseases can cause sudden cardiac death in older and younger individuals. Two groups of familial diseases are responsible for sudden cardiac death: cardiomyopathies (mainly hypertrophic cardiomyopathy, dilated cardiomyopathy, and arrhythmogenic cardiomyopathy) and channelopathies (mainly long QT syndrome, Brugada syndrome, short QT syndrome, and catecholaminergic polymorphic ventricular tachycardia). This review focuses on cardiac channelopathies, which are characterized by lethal arrhythmias in the structurally normal heart, incomplete penetrance, and variable expressivity. Arrhythmias in these diseases result from pathogenic variants in genes encoding cardiac ion channels or associated proteins. Due to a lack of gross structural changes in the heart, channelopathies are often considered as potential causes of death in otherwise unexplained forensic autopsies. The asymptomatic nature of channelopathies is cause for concern in family members who may be carrying genetic risk factors, making the identification of these genetic factors of significant clinical importance.
\end{abstract}

Keywords: sudden cardiac death; arrhythmias; channelopathies; genetics

\section{Introduction}

Sudden death (SD) is defined as an unexpected natural death occurring within an hour after the onset of symptoms. When unwitnessed, SD refers to the death of an individual within $24 \mathrm{~h}$ after being seen alive and in a normal state of health [1,2]. Further, the term sudden unexplained death (SUD) is used in cases where an exhaustive postmortem examination fails to determine a conclusive cause of death [3]. Nearly $85 \%$ of all SD are of cardiac origin and sudden cardiac death (SCD) is a leading cause of death in Western countries [4,5]. Subjects are otherwise healthy or may have been diagnosed with a disease not severe enough to predict a fatal outcome. In the last ten years, prospective epidemiological studies [6-10] have identified rates between 50 and 100 in every 100,000 deaths [11,12]. Most cases of SCD in patients over 40 years old are the result of coronary heart disease or an ischemic event $[13,14]$. In contrast, SCD in the young-adult population ( $<35$ years old) is often caused by arrhythmic syndromes with or without structural heart alterations. These diseases result from genetic alternations, which can be inherited [15]. Cardiomyopathies, such as hypertrophic cardiomyopathy (HCM), dilated cardiomyopathy (DCM), and arrhythmogenic cardiomyopathy $(\mathrm{AC})$ are characterized by the presence of structural heart alterations that lead to 
SCD-related arrhythmias. These arrhythmias are often the result of genetic alterations in proteins found in the sarcomere, desmosomes, or cytoskeleton. Channelopathies, such as long QT syndrome (LQTS), Brugada syndrome (BrS), short QT syndrome (SQTS), and catecholaminergic polymorphic ventricular tachycardia (CPVT) are characterized by malignant arrhythmias in a normal heart resulting from genetic alterations in ion channels or associated proteins. Recent studies have found that about $30 \%$ of negative autopsies in young individuals ( $<15$ years) could possibly be explained by pathogenic variations in channelopathy-related genes [16].

In recent years, technological advances in the field of genetics have facilitated the study of a high number of genes in a short period of time. The application of this technology to cardiology has facilitated the identification of several key genes associated with SCD. As a result, genetic testing has been progressively incorporated into clinical diagnosis, assisting with the identification of the cause of disease in clinically affected patients and in unsolved post-mortem cases, as well as identifying risk factors in asymptomatic carriers [17]. These advances have also generated an increasing volume of genetic information that needs to be carefully interpreted, especially in cases where variants of uncertain significance have been identified. In such cases, a multidisciplinary team of clinicians, cardiologists, and genetic counselors works together to appropriately interpret the results both at the genetic and clinical level. Inherited cardiac diseases are characterized by variable expressivity and incomplete penetrance even among family members, representing additional challenges in the interpretation of genetic results. This review describes recent advances in clinical diagnosis and the genetics of cardiac channelopathies.

\section{Channelopathies: An Overview}

The heart is an electromechanical pump electrically triggered by the generation and propagation of an action potential (AP) across myocytes. This is followed by a period of muscle contraction and relaxation until the generation of the next impulse [18,19]. Myocardial AP is generated by ionic changes across the membrane. The sequential activation and inactivation of ion channels that conduct depolarizing, inward currents $\left(\mathrm{Na}^{+}\right.$and $\left.\mathrm{Ca}^{2+}\right)$ and repolarizing, and outward currents $\left(\mathrm{K}^{+}\right)$enable transmembrane ion currents and, subsequently, AP formation $[18,20]$. The direction of ion currents is determined by the electrochemical gradient of the corresponding ions. Cardiac ion channel expression and properties are distinct in different regions of the heart, leading to unidirectional propagation of electrical activity. Changes in AP, synchronization, and/or propagation of electrical impulse predispose to potentially malignant arrhythmias $[18,19]$. These modifications may be induced by pathogenic variants in genes encoding ion channels or associated proteins. As mentioned above, the main cardiac channelopathies associated with SCD are BrS, LQTS, SQTS, and CPVT.

\section{Brugada Syndrome}

Twenty-five years ago, eight individuals sharing the same phenotype were reported to have been resuscitated from SCD caused by documented ventricular fibrillation (VF) showing an ST segment elevation in the right precordial leads in a structurally normal heart [21]. In 1996, the term "Brugada syndrome" was first used to define the "right bundle branch block, persistent ST segment elevation, and sudden death syndrome" [22]. Some years later, BrS was reported as "sudden unexplained nocturnal death syndrome", also called bangungut in the Philippines, pokkuri in Japan, or lai tai in Thailand, all characterized by nocturnal death primarily in males around 40 years of age [23]. Currently, the global prevalence of $\mathrm{BrS}$ varies from five to 20 in every 10,000 individuals, and there is a strong gender disequilibrium ratio of three to one (male to female) likely due to the influence of hormones [24]. This rate is more than likely underestimated, however, due to the presence of concealed forms of the disease and to ethnic and geographic differences [24]. BrS is endemic in Southeast Asia and is the second cause of death among young men after car accidents [25], showing a male-dominated disequilibrium up to 9:1 [26]. The first manifestation of the disease usually occurs during rest or sleep likely due to high vagal tone [27]. The phenotype is also age-dependent; hence, adults show more 
abnormalities than adolescents [28] probably also resulting from hormonal differences. In the pediatric population, despite scarce information published to date, the incidence is very low and lacks a male prevalence, perhaps due to the low levels of testosterone found in children of both genders [27].

\subsection{Clinical Presentation and Diagnosis}

$\mathrm{BrS}$ is clinically characterized by ST segment elevation in leads V1-V3 of an electrocardiogram (ECG) [29]. Recent reports suggest that BrS could be responsible for $4 \%-12 \%$ of all SD and up to $20 \%$ of SD in patients with structurally normal hearts [21]. The diagnosis of $\mathrm{BrS}$ is based on clinical and electrocardiographic features and despite continuous advances, incomplete penetrance, and dynamic ECG manifestations confer difficulties in BrS diagnosis. Hence, patients may remain completely asymptomatic or suffer SCD secondary to polymorphic ventricular tachycardia (PVT)/VF [22]. Frequently, SCD can be the first manifestation of the disease [23]. Even though the cause has not been elucidated, structural myocardial abnormalities have been reported in BrS patients [24,25].

Originally, BrS was reported as "persistent ST elevation and with right bundle branch block", however, both criteria are no longer necessary for diagnosis. Currently, clinical diagnosis requires an ST segment elevation in one of the right precordial leads at baseline or after the use of sodium blockers. Three types of ECG have been described (types I, II and III). Type I is characterized by ST segment elevation followed by a negative $\mathrm{T}$ wave, with little or no isoelectric separation, with a "coved morphology" [26] (Figure 1). The ECG types II and III present with saddleback-shaped patterns, with a high initial augmentation followed by an ST elevation greater than $2 \mathrm{~mm}$ for type II and less than $2 \mathrm{~mm}$ for type III. The second Brugada consensus report proposed that only type I is diagnostic for BrS [21] and, in 2013, it was proposed that both a spontaneous type I pattern and a provoked type I pattern (with baseline type II or III pattern) in at least one right precordial lead (V1 or V2) should be considered sufficient for a definitive diagnosis of BrS [27]. This pattern may be spontaneous or induced by a pharmacological test using Class I antiarrhythmic drugs (AAD) [22]. Types II and III ECG patterns are suggestive, but not diagnostic, of BrS. It has also been reported that a type I pattern is observed in nearly $25 \%$ of tracings and most ECG will normalize at follow-up. Therefore, the current diagnosis of BrS is based on a type I ECG pattern and any of the following clinical features: documented VF, PVT, inducibility of VT with programmed electrical stimulation, family history of SCD at younger than 45 years of age, covered-type ECG in family members, unexplained syncope, or nocturnal agonal respiration [21].

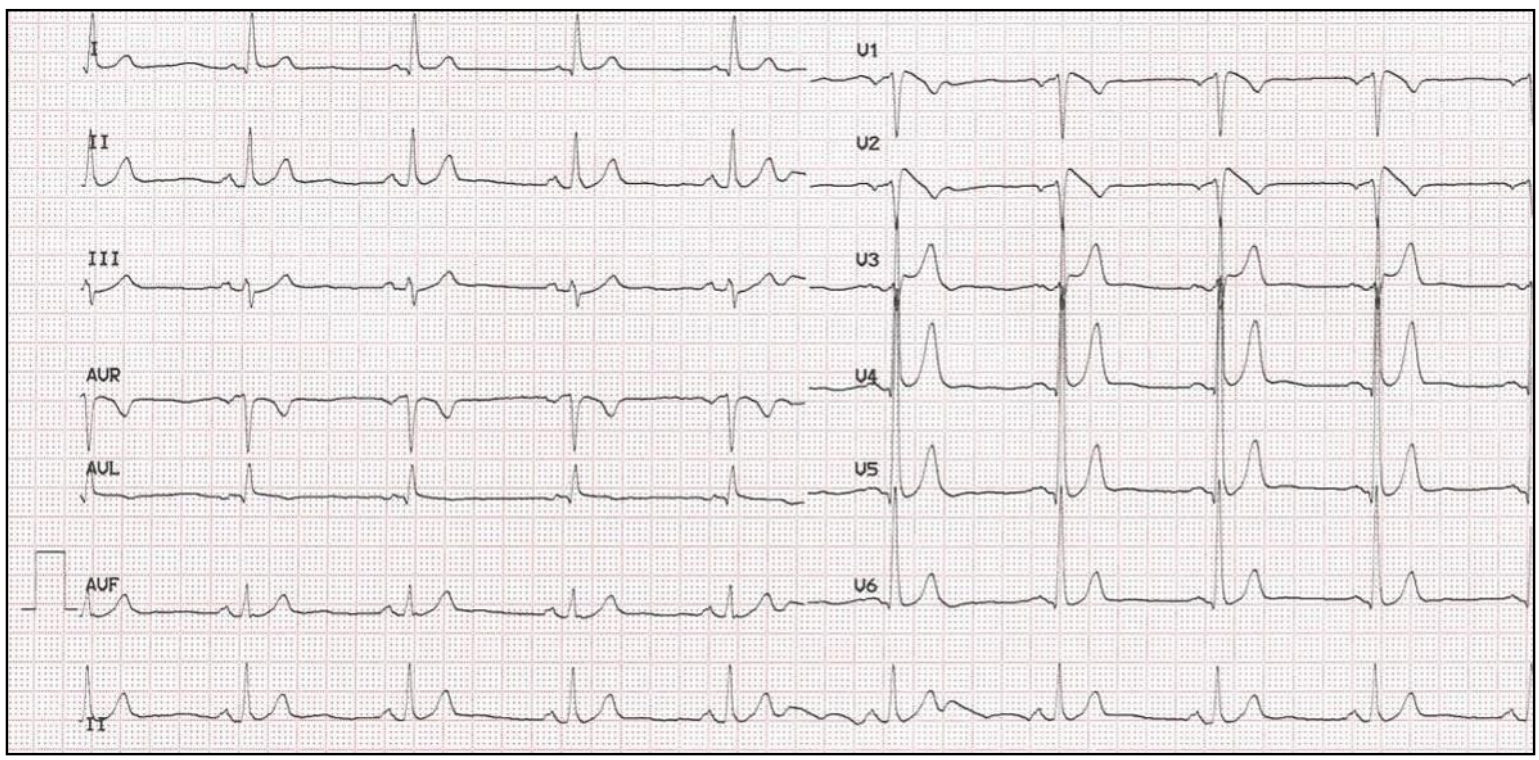

Figure 1. Brugada syndrome type I electrocardiogram (ECG) from a 59-year-old male. 


\subsection{Genetics}

BrS is a channelopathy with an autosomal-dominant pattern of inheritance. The first genetic alteration associated with BrS was identified in the SCN5A gene encoding the $\alpha$-subunit of the cardiac sodium channel, Nav1.5 [28]. Since then, more than 450 pathogenic variants have been identified in 24 genes encoding sodium, potassium, and calcium channels or associated proteins (ABCC9, CACNA1C, CACNA2D1, CACNB2, FGF12, GPD1L, HCN4, HEY2, KCND2, KCND3, KCNE3, KCNE5, KCNH2, KCNJ8, PKP2, RANGRF, SCN10A, SCN1B, SCN2B, SCN3B, SCN5A, SEMA3A, SLMAP, and TRPM4) [23] (Figure 2).

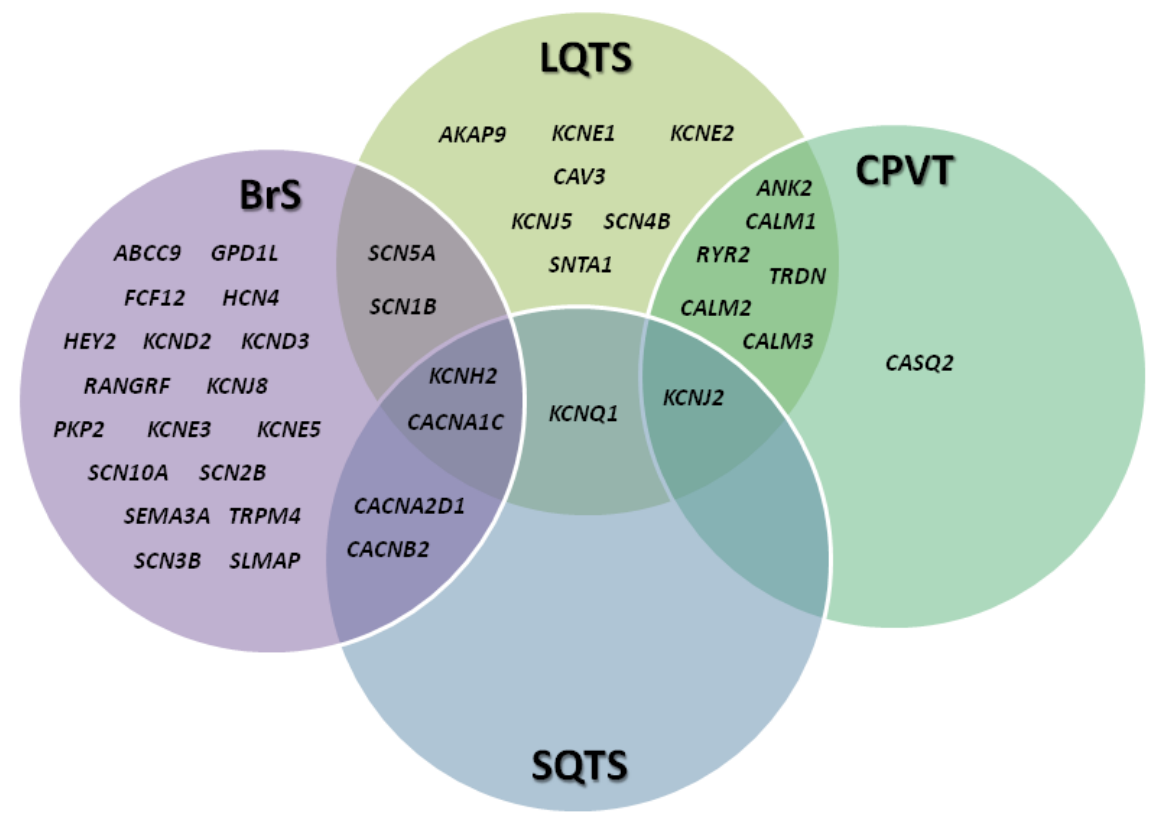

Figure 2. Diagram of the overlap between the genes associated with Brugada syndrome (BrS), short QT syndrome (SQTS), long short QT syndrome (LQTS) and catecholaminergic polymorphic ventricular tachycardia (CPVT).

Approximately $20 \%-25 \%$ of $\mathrm{BrS}$ patients are genetically diagnosed with pathogenic variations in SCN5A. However, known BrS-susceptibility genes can only explain $30 \%-35 \%$ of clinically diagnosed cases, indicating that $65 \%-70 \%$ of $\mathrm{BrS}$ patients remain genetically unsolved [23]. Besides SCN5A, pathogenic variations in $S C N 1 B$ [30], $S C N 2 B$ [31], and $S C N 3 B$ [32], which encode the $\beta$ subunits of the Nav1.5 sodium channel, and SCN10A [33], encoding the neuronal sodium channel Nav1.8, have been discovered to modify the sodium channel's function. While mutations in SCN1B, SCN2B, and $S C N 3 B$ are rare, several studies have reported that $S C N 10 A$ mutations account for $2.5 \%-16 \%$ of BrS patients [33-36].

Calcium channels (CACNA1C, $C A N B 2 b$ and $C A C N A 2 D 1)$ have also been reported as BrS-susceptibility genes. Pathogenic variants in $C A C N A 1 C$ and $C A C N B 2$, which encode the $\alpha 1 c$ and $\beta$-2b subunits of the L-type cardiac $\mathrm{Ca}^{2+}$ channel, respectively, cause a decrease in $\mathrm{I}_{\mathrm{Ca}}$ channels and make up nearly $11.5 \%$ of $\mathrm{BrS}$ cases in which patients present with a syndrome overlapping the typical BrS ECG pattern with a short QT interval $[37,38]$. CACNA2D1, which encodes the $\alpha-2 / \delta$ subunit of the L-type cardiac $\mathrm{Ca}^{2+}$ channel, regulates the current density and activation/inactivation kinetics of the $\mathrm{Ca}^{2+}$ channel and is a gene associated with BrS but in a low frequency [39].

Putative gain-of-function mutations in genes encoding channels that conduct outward potassium currents have also been reported in a few BrS cases. Gain-of-function mutations in KCND3 have been implicated in BrS [40] with an enhanced $\mathrm{I}_{\text {to }}$ current gradient within the right ventricle where KCND3 expression is the highest. Gain-of-function mutations in KCND2 have been associated with J-wave 
syndromes, including BrS [41]. KCNE3, encoding MiRP2, decreases the $\mathrm{I}_{\text {to }}$ current by interacting with the channel Kv4.3 and results in increased $\mathrm{I}_{\text {to }}$ magnitude and density in the human heart, which could underlie the pathogenesis of BrS-pattern ECG [42]. KCNE5 is located on the X chromosome and encodes an auxiliary $\beta$ subunit for $\mathrm{K}$ channels. Mutations in KCNE5 cause modifications to potassium channels that lead to an increase in the $\mathrm{I}_{\text {to }}$ current and have been linked to BrS [43]. Functional KATP channels have an octameric subunit structure with four pore-forming subunits (Kir6.1) encoded by KCNJ8 and four sulfonylurea receptors (SUR2A) encoded by ABCC9. Pathogenic variants in KCNJ8 or ABCC9 may result in a severe arrhythmic phenotype typical of BrS [44]. Mutations in KCNH2 have mainly been associated with LQTS; however, a few pathogenic variants have also been reported in patients with a short-QT interval and Brugada ECG $[45,46]$.

Genes encoding proteins that interact with sodium, calcium, and potassium channels have also been reported as being associated with BrS. RANGRF, which encodes MOG1, can impair the trafficking of Nav1.5 to the membrane, leading to $\mathrm{I}_{\mathrm{Na}}$ reduction and clinical manifestation of $\mathrm{BrS}$ [47]. GPD1L may affect trafficking of the cardiac sodium channel to the cell surface and regulate cardiac sodium current [48], but has only been implied in a small number of BrS cases [49]. SLMAP, which is found in T-tubules and in the sarcoplasmic reticulum and has an unknown function, is known to cause BrS by modulating the intracellular trafficking of the Nav1.5 channel [50]. Pathogenic variations in PKP2, the primary gene responsible for arrhythmogenic right ventricular cardiomyopathy, have also been recently associated with BrS [51,52]. Pathogenic mutations in TRPM4 alter the resting potential of the membrane and changes in the function of this channel may reduce the availability of sodium channels, ultimately leading to BrS [53]. FGF12 is the major fibroblast growth factor homologous factor expressed in the human ventricle and is implicated in an $\mathrm{Na}^{+}$channel loss-of-function phenotype consistent with BrS diagnosis [54]. HEY2, which encodes the transcriptional repressor hairy/enhancer-of-split related to YRPW motif protein, has been found to play a role in the regulation of SCN5A expression and conduction velocity in the heart, suggesting that $\mathrm{BrS}$ may originate from altered transcriptional programming during cardiac development [55]. HCN4 encodes the hyperpolarization activated cyclic nucleotide-gated potassium channel 4, a voltage-gated ion channel mediating the pacemaker current in the heart, and although its causative role remains unclear, it has been reported in a few patients with $\mathrm{BrS}$ [56]. The SEMA3A gene is a protein that inhibits $\mathrm{Kv} 4.3$ and is associated with the BrS gene through a Kv4.3 gain-of-function mechanism [57]. Concerning copy number variation (CNV), one large-scale deletion of the SCN5A gene was identified as a cause of the disease [58] and a recent study identified a duplication in one of 220 patients analyzed $(0.45 \%)$ [59]. However, several reports conclude that genetic imbalances are uncommon in BrS families [60-62]. Despite the recent improvements in BrS diagnosing, only $30 \%-35 \%$ of cases are genetically diagnosed; $25 \%-30 \%$ carry a pathogenic variant in SCN5A [63].

It is important to notice that, except for SCN5A and GPD1L, most of the genes associated with BrS susceptibility have been identified only in single patients, in a few unrelated patients, or in small families through candidate gene analysis. Therefore, further investigation is needed before genes are implicated in the pathogenesis of BrS or any other disease and in order to avoid false-positive reports of causality in the context of genetic counseling [64]. Consequently, current clinical guidelines only recommend genetic analysis of the SCN5A gene [65].

\section{Long QT Syndrome}

More than 50 years ago, a family with concomitant deafness, mutism, and a peculiar heart disease was described [66]. The ECG revealed a pronounced prolongation of the QT interval in all cases. Three of the deaf-mute children died suddenly at ages four, five, and nine. One year after, in 1958, Levine et al. reported a case of an 8-year-old boy who died suddenly after having been previously diagnosed with congenital deaf-mutism, attacks of unconsciousness, and an ECG with a prolonged QT interval and large T waves, but no other objective evidence of organic heart disease or any other diseases were observed upon post-mortem examination [67]. Shortly thereafter, Romano et al. [68] and Ward [69] published QT prolongation in one parent and several children from two different 
families, all of whom possessed normal hearing but experienced recurrent syncope and SD. Since 1975, the unifying name of "long QT syndrome" has included both the Jervell-Lange-Nielsen and the Romano-Ward syndromes, associated with and without deafness, respectively [70].

LQTS can be congenital or acquired. While congenital LQTS is associated with mutations in ion channels and/or associated proteins [71], acquired LQTS is generally associated with drugs and electrolyte imbalance (hypokalemia, hypocalcaemia, and hypomagnesaemia). The prevalence was assumed to be between $1 / 5000$ and $1 / 20,000$, but a study performed in children suggested that the prevalence of LQTS in infants is closer to 1/2000 [72]. Gender is a major factor in determining the course and clinical manifestation of the LQTS. Even though the QT interval duration is similar between young boys and girls, differences appear during puberty in which boys present with a shorter QT interval [73]. In congenital LQTS, women have longer QT intervals than men [74,75]. Therefore, women are more often clinically diagnosed than men despite equal genotype sex-distribution [76]. Curiously, the probability of a first cardiac event is higher in males by age 15 but decreases after puberty $[74,77]$. Sex hormones are suggested to play an important role in conferring these gender differences; different phases of the menstrual cycle, pregnancy, and the postpartum period are all associated with changes in QT duration and the incidence of PVT in LQTS patients [76,78]. However, the first cardiac event tends to be more often fatal in males than in females [77]. Additionally, in response to QT prolonging drugs, women are also more at risk of developing arrhythmias than men [79-81].

\subsection{Clinical Presentation and Diagnosis}

LQTS is an inherited arrhythmia characterized by a prolonged QTc interval in the 12-lead ECGs (with QTc values $>470 \mathrm{~ms}$ for males and $>480 \mathrm{~ms}$ for females, representing approximate 99th percentile values) (Figure 3). The clinical manifestations of LQTS can be variable, ranging from asymptomatic patients diagnosed through family screening, to SCD, syncope, convulsions, malignant ventricular arrhythmias, VF, and typically torsade de pointes [82-87]. SD usually occurs in healthy children and teenagers and in physically or emotionally stressful situations. LQTS is a cardiac channelopathy characterized by prolonged ventricular repolarization and life-threatening arrhythmias and displays incomplete penetrance and variable expressivity [88]. All symptomatic individuals should be treated, as there is a high lethality among symptomatic and untreated patients [27]. Exceptions exist and patients with modest or normal QT intervals can also experience symptoms. However, in general, the longer QT interval increases the risk of malignant arrhythmias. In addition, there is evidence that risk of malignant arrhythmia increases when QTc exceeds 500-550 ms [89,90].

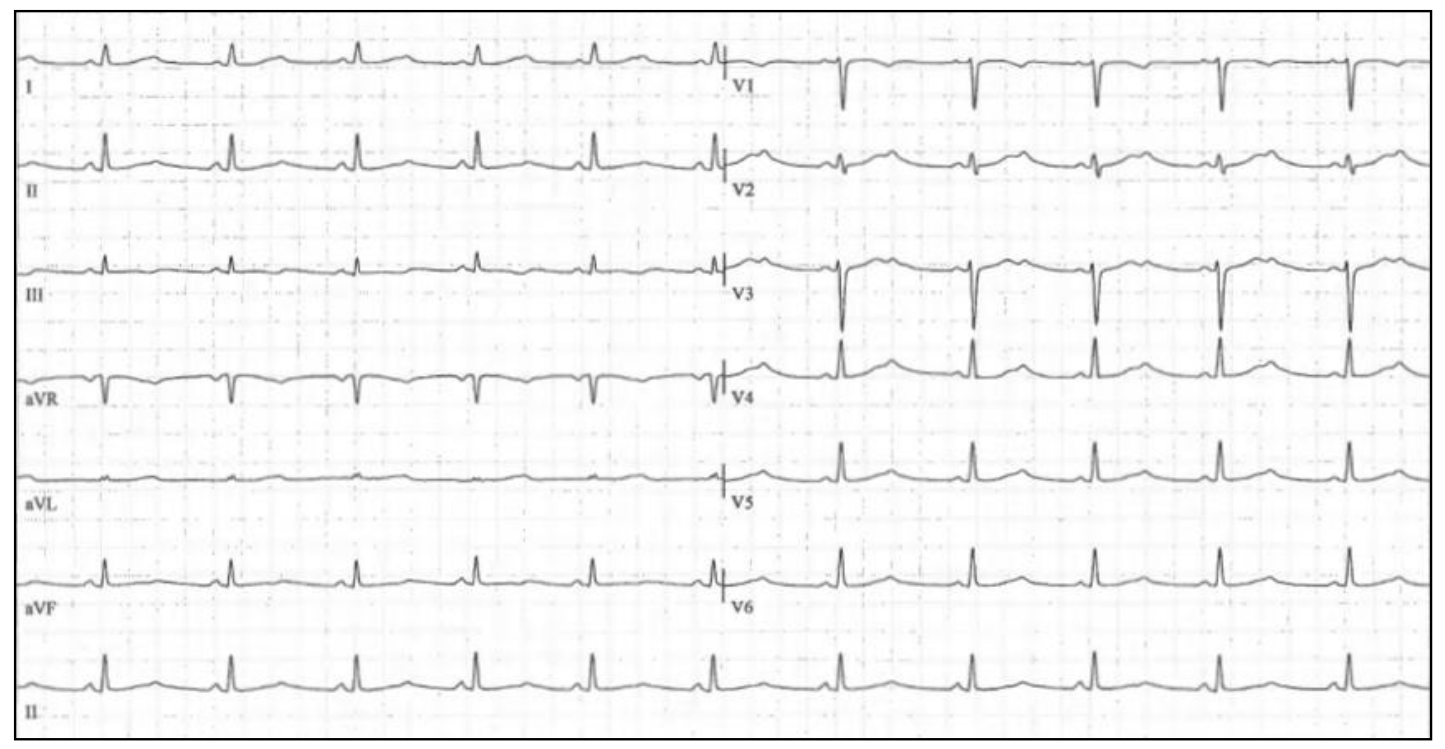

Figure 3. ECG from a 20-year-old patient with LQTS. 
The diagnosis of LQTS is based on clinical and electrocardiographic features. In 1985, Schwartz et al. published the first description of diagnostic criteria for LQTS, which remain essentially valid for quick assessment [91]. However, the approach became quantitative with the presentation in 1993 of a diagnostic score known as the "Schwartz score" [92], which has since been updated [93,94]. Points are assigned based on ECG, clinical history, and family history criteria. As such, the diagnosis of LQTS is established by a "Schwartz score" of $\geq 3.5$ without a secondary cause for QT prolongation and/or by the presence of a QTc interval $\geq 500 \mathrm{~ms}$ in repeated ECGs without a secondary cause for QT prolongation and/or by the presence of a pathogenic variant in one of the genes known to be associated with LQTS [27]. Additionally, LQTS can be diagnosed if QTc is between 480 and $499 \mathrm{~ms}$ in patients with unexplained syncope without a secondary cause for QT prolongation and in the absence of a pathogenic genetic variant [27].

A careful analysis of T-wave morphology can also provide useful diagnostic information as each of the major LQTS genotypes correlates with specific ST-T wave patterns $[95,96]$. For example, LQT1 has a broad-based T wave; a low-amplitude and notched T wave are characteristic of LQT2; LQT3 has a late-appearing T wave [95]; and LQT7 has a mild QT prolongation with a prominent $U$ wave [97]. Moreover, certain genotypes may be associated with changes in heart rate [98] and prominent $U$ waves and T-U complexes are commonly identified [85]. Furthermore, T-wave alternation is a sign of electrical instability and can be a precursor to ventricular tachycardia (VT) or fibrillation [99-101].

\subsection{Genetics}

The genetic heterogeneity of LQTS has led to its classification into subtypes based on genetic loci. In 1991, a linkage analysis was performed in a multigenerational family with many affected relatives and the genetic defect was mapped to the small arm of chromosome 11 [102]. However, in 1994, linkage analysis in other cohorts identified loci on chromosomes 7 and 3, demonstrating that not all related individuals with LQTS share the same locus [103-105]. To date, pathogenic variants associated with LQTS have been identified in 19 genes: 15 following an autosomal-dominant pattern of inheritance (AKAP9, ANK2, CACNA1C, CALM1, CALM2, CALM3, CAV3, KNCE2, KCNH2, KCNJ2, KCNJ5, RYR2, SCN1B, $S C N 4 B, S C N 5 A$ and SNTA1), one following an autosomal-recessive pattern (TRDN), and two following both autosomal-dominant and -recessive patterns (KCNQ1 and KCNE1) (Figure 2).

Approximately $85 \%$ of clinically diagnosed patients have a mutation in one of these genes [106]. The three major LQTS-susceptibility genes are KCNQ1, KCNH2, and SCN5A, and mutations in these genes are associated with about $75 \%$ of patients with a clinical LQTS diagnosis. The remaining 16 genes are responsible for nearly $10 \%$ of LQTS cases. KCNQ1 (LQT1) encodes the $\alpha$-subunit of the voltage-gated potassium channel and mediates the slow component of the delayed rectifier potassium current $\left(I_{\mathrm{Ks}}\right)$ [107]. Pathogenic variations in $K C N Q 1$ reduce $I_{\mathrm{Ks}}$, prolonging the repolarization phase of the AP $[108,109]$. The KCNH2 gene encodes the $\alpha$-subunit of the voltage-gated potassium channel and mediates the rapidly activating component of the delayed rectifying potassium current $\left(I_{\mathrm{Kr}}\right)$. Pathogenic variations in $K C N H 2$ result in reduced $I_{\mathrm{Kr}}$ and delayed cardiac repolarization leading to a prolonged QT interval [110]. Gain-of function variants in SCN5A (LQT3) induce an increased late inward Nav1.5 current that slows cardiac repolarization, also causing a prolonged QT interval [111]. All other known LQTS-associated genes are responsible in about $10 \%$ of LQTS cases. The ANK2 gene (LQT4) encodes the protein ankyrin-B which is involved in the coordinated assembly of the $\mathrm{Na} / \mathrm{K}$ ATPase, $\mathrm{Na} / \mathrm{Ca}$ exchanger, and the inositol triphosphate receptor. A decrease in the role of ankyrin-B alters calcium homeostasis, prolonging repolarization [112]. The first auxiliary proteins implicated in the pathogenesis of LQTS through their modulatory effect on $I_{\mathrm{Ks}}$ and $I_{\mathrm{Kr}}$ were KCNE1 (LQT5) and KCNE2 (LQT6), respectively $[113,114]$. KNCE1 encodes the $\beta$-subunit of Mink and KCNE2 the $\beta$-subunit of MiRP1. LQT7, or Andersen-Tawil syndrome, is caused by loss-of-function mutations in $K C N J 2$, which encode for the inward rectifier potassium channel $\left(I_{\mathrm{K} 1}\right)$. Andersen-Tawil syndrome is a form of LQTS accompanied by extracardiac manifestations that include dysmorphic physical features and periodic paralysis $[115,116]$. 
LQT8 occurs due to gain-of-function variants in the CACNA1C gene that induce slowed inactivation of Cav1.2. This fact induces an increased influx of calcium, prolongation of AP, and arrhythmias $[117,118]$. Several point mutations have been described in CACNA1C as being associated with a rare multi-systemic syndrome called Timothy syndrome [119-121]. Timothy syndrome is characterized by several physical and/or developmental abnormalities in addition to the classic phenotype of QT prolongation and an increased risk of SCD. CAV3 (LQT9) encodes the Caveolin-3 protein that may play a role in the compartmentalization and regulation of resident ion channels in the caveolae. Abnormalities in CAV3 have the potential to modify Nav1.5 in a similar manner to that observed with LQT3 through an increased late inward current [122]. This also occurs with pathogenic variants in SCN4B (LQT10), which encodes a $\beta$-subunit of the sodium channel [123], and pathogenic variants in SNTA1 (LQT12), which encodes the alpha1-syntrophin protein [124]. AKAP9 encodes the kinase-A anchor protein-9 and mutations in this gene (LQT11) impair $I_{\mathrm{Ks}}$ increase, leading to a clinical phenotype similar to that of LQT1 and LQT5 $[125,126]$. Pathogenic variants in KCNJ5, which encodes the inwardly-rectifying potassium channel, result in reduced membrane expression of the protein [127].

Mutations in CALM1 (LQT14), CALM2 (LQT15), and CALM3 (LQTS16), encoding calmodulin, disrupt calcium-ion binding to the protein [128-130]. A recent study identified a mutation in $S C N 1 B$ in a LQTS patient and demonstrated that the SCN1B mutation increases late sodium current [131]. A long QT interval has been also associated with a patient carrying a mutation in the cardiac ryanodine receptor gene $R Y R 2$ [132]. TRDN, which encodes triadin protein, has been identified as a novel autosomal-recessive LQTS-susceptibility gene. Additionally, pathogenic variants in KCNQ1 (JLN1) and KCNE1 (JLN2) have also been identified as autosomal-recessive forms of Jervell and Lange-Nielsen syndrome attributable to a decrease in the $I_{\mathrm{Ks}}$. Jervell and Lange-Nielsen syndrome is characterized by neurosensorial deafness and a markedly prolonged QT interval [133].

\section{Short QT Syndrome}

In 2000, Gussak et al. reported two probands with idiopathic familial persistently short QT intervals [134]. Three years later, Gaita et al. reported six patients from two unrelated families with very short QT intervals at ECG, syncope, palpitations, and a strong family history of SCD [135]. SQTS is a rare channelopathy with an estimated prevalence of less than 1 in 10,000 [136-139]. Currently, SQTS has been described in only a few families worldwide and all probands present with a QTc below $320 \mathrm{~ms}$ without evident structural heart disease [140]. The largest available case series published so far showed that most patients have experienced symptoms and that the manifestation of an abbreviated repolarization was predominant in males [136]. However, even if QTc intervals are significantly longer in females than in males, women should not be regarded as low-risk patients because the risk of experiencing cardiac arrest appears to be similar in males and females. Additionally, SQTS shows a peak of incidence during the first year of life, followed by a quiescent phase encompassing adolescence and another peak at old age [136,141].

\subsection{Clinical Presentation and Diagnosis}

SQTS is a rare inheritable cardiac channelopathy characterized by abnormally short QT intervals and an increased propensity to develop atrial and ventricular tachyarrhythmia in the absence of structural heart disease. Cardiac arrest seems to be the most frequent symptom (up to 40\%) [136]. Palpitations are a common symptom (30\%), followed by syncope (25\%) and atrial fibrillation (AF), which are the first symptoms of the disease in up to $20 \%$ of patients. The episodes may occur in a wide range of situations such as in reaction to loud noise, at rest, during exercise, and during daily activity [142]. Some patients show additional QT shortening during bradycardia. To date, there is no evidence to assume that a shorter QTc interval could predispose to a higher risk of ventricular arrhythmias. In fact, the prognosis of patients with asymptomatic SQTS remains undefined. SQTS can 
be congenital or acquired, with the latter associated with hypercalcemia, hyperkalemia, acidosis [143], and drugs [144].

ECG constitutes the basis of diagnosis (Figure 4). However, SQTS diagnosis should be based on several findings, including a short QTc interval ( $\leq 360 \mathrm{~ms}$ in males; $\leq 370 \mathrm{~ms}$ in females) [145-147], syncope, episodes of VF or PVT, family history of short QT interval, syncope or VF, occurrence of AF, and no obvious heart disease or extracardiac conditions that abbreviate QT interval [85]. Additionally, there are several other ECG findings that may facilitate the correct diagnosis of SQTS such as the presence of tall, peaked, symmetrical, and narrow-based T waves, prominent $U$ waves [148], depression of the PQ segment [149], or a QRS complex directly followed by a T wave [150].

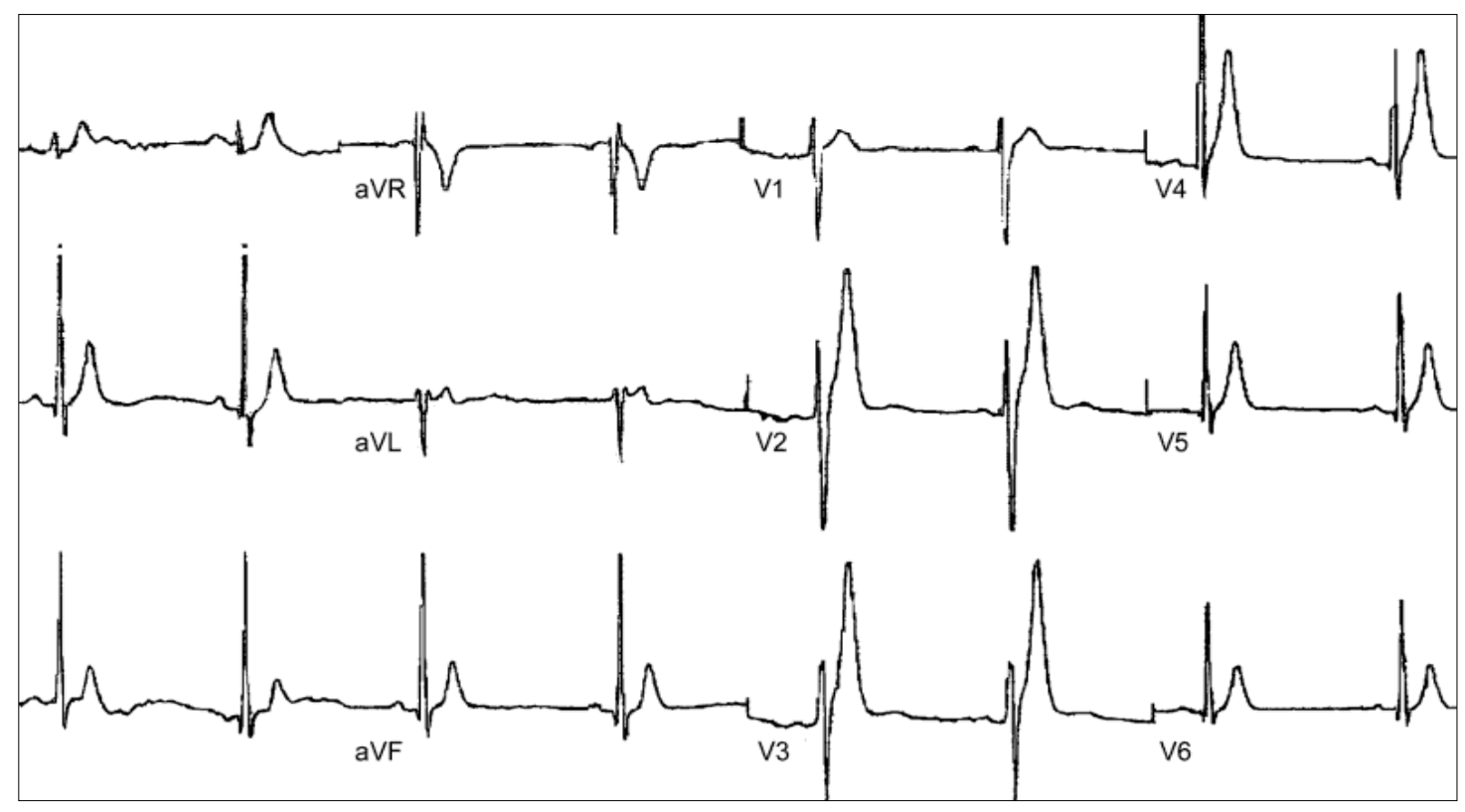

Figure 4. ECG from a patient with SQTS.

\subsection{Genetics}

SQTS is a channelopathy with an autosomal-dominant pattern of inheritance and high penetrance. Currently, genetic alterations associated with SQTS have been identified in six genes (KCNQ1, KCNH2, $K C N J 2, C A C N A 1 C, C A C N B 2$ and CACNA2D1) (Figure 2). Despite the fact that a familial association is present in the majority of patients, the yield of genetic screening is low and varies between $15 \%$ and $40 \%[140,151,152]$. The most prevalent subtype of SQTS is associated with gain-of-function mutations in KCNH2 (SQTS1) that increase current flow through the channel and shorten the AP duration and QT interval $[135,153]$. Pathogenic variants in KCNQ1 (SQTS2) increase the repolarizing current, shortening the QT interval [108]. SQTS3 occurs secondary to gain-of-function mutations in KCNJ2, leading to an increase in the outward $I_{K 1}$ current and an acceleration of the final phase of repolarization [154]. The QT interval can also be shorted by a reduction in depolarizing currents. Loss-of-function mutations in the $\alpha 1-, \beta 2-$, and $\alpha-2 / \delta$ subunits of the L-type calcium channel (CACNA1C -SQTS4-, CACNB2 -SQTS5-, and CACNA2D1 -SQTS6-, respectively) are associated with a shortening of the QT interval and precordial ST elevation reminiscent of $\mathrm{BrS}[37,155]$.

\section{Catecholaminergic Polymorphic Ventricular Tachycardia}

CPVT is a pathological condition whereby intense physical exercise or acute emotional stress can trigger abnormal heartbeat-i.e., ventricular tachycardia-that can lead to dizziness, fainting (syncope), and in worst cases to cardiac arrest and sudden death. In 1960, Berg [156] described three sisters with multifocal ventricular extrasystoles without any other signs of structural heart disease. 
In two of the children, the arrhythmia was accompanied by Adams-Stokes syndrome and one died suddenly. The direct cause of these attacks was believed to be VT or VF. In 1975, the electrophysiological and hemodynamic findings in a six-year-old girl with bidirectional tachycardia were not caused by digitalis, but precipitated by effort and emotion [157]. Following the description of "catecholaminergic polymorphic ventricular tachycardia", the first comprehensive study of CPVT was published by Leenhard et al. in 1995 [158]. They described 21 children suffering from stress- or emotion-induced syncope, with no evidence of structural heart disease and normal QT intervals. Seven patients presented with a family history of syncope or SD, suggesting a genetic origin of CPVT.

CPVT is a rare disease with an estimated prevalence of 1:10,000 [159,160]. CPVT commonly manifests at an early age and has poor spontaneous outcome [161]. Gender plays an important role in the etiology, pathogenesis, and cardiac risk stratification of patients with CPVT. Earlier onset of clinical symptoms and a significantly higher risk of cardiac events at a young age is observed in males [162].

\subsection{Clinical Presentation and Diagnosis}

CPVT is characterized by polymorphic premature ventricular contractions or polymorphic ventricular tachyarrhythmias in genetically predisposed individuals under physical or emotional stress. Syncope is the first clinical manifestation of CPVT patients and less prevalent signs and symptoms include dizziness or palpitations [163]. Presentation of most arrhythmic events occurs during childhood, between seven and 11 years, and more than $60 \%$ of affected individuals have experienced a syncopal episode or cardiac arrest by age 20 [164]. Generally, there is a two-year delay between the first and second syncope episode in patients with CPVT. Family history of juvenile SCD and/or stress-related syncope is present in approximately $30 \%$ of patients [165]. CPVT is one of the most malignant and yet insufficiently recognized primary electrical diseases of the heart. It exhibits incomplete penetrance, which has been reported to be around 78\% [166], and has variable expressivity.

The basal ECG of patients with CPVT tends to be normal, although some authors have reported lower-than-normal heart rates, and others have observed prominent $U$ waves [167]. Diagnostic characteristics of CPVT are unmasked by exercise ECG [168] (Figure 5). Usually, the beginning of ventricular arrhythmias is 100-120 beats/min [169]. In situations where exercise persists, the premature ventricular complexes may progress to bigeminy and non-sustained ventricular tachyarrhythmia; if exercise is maintained, the duration of VT progressively increases and may become sustained [170].

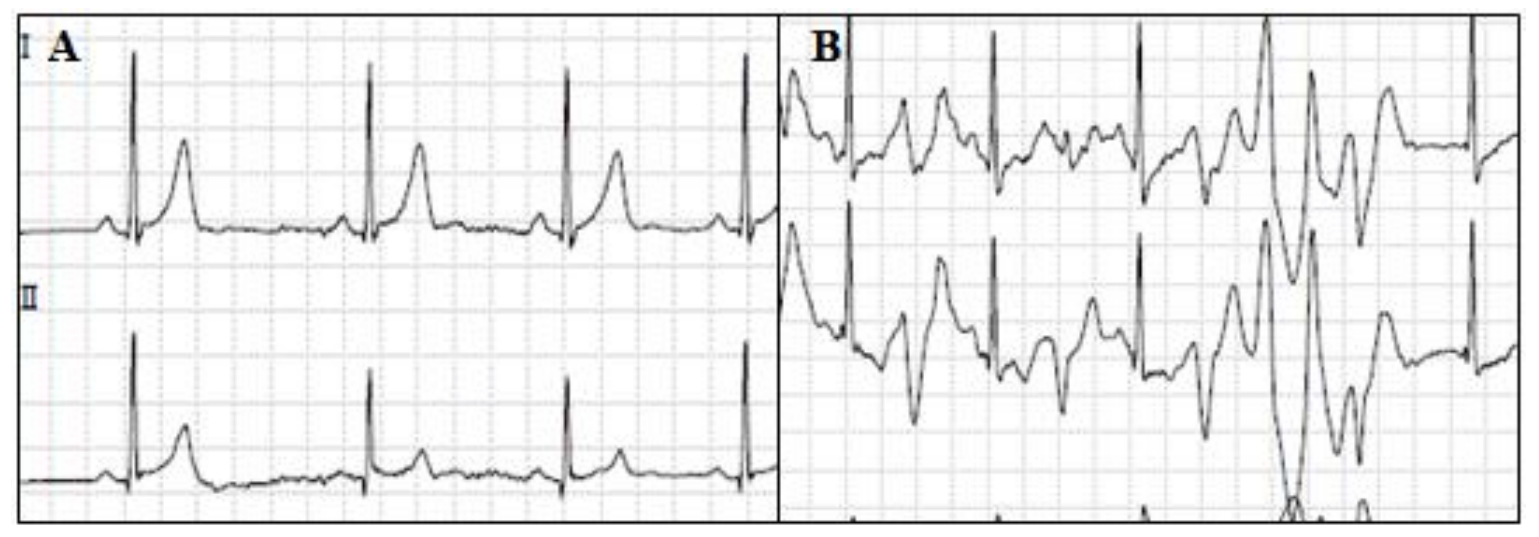

Figure 5. Exercise ECGs from a patient with CPVT. (a) Basal; (b) Bidireccional ventricular arrhythmia.

\subsection{Genetics}

CPVT is a channelopathy with both autosomal-dominant and, less frequently, autosomal-recessive inheritance patterns. The first CPVT-associated variants were identified in 2001 in the gene encoding the cardiac ryanodine receptor $(R Y R 2)$ in four of 12 probands presenting with typical CPVT in the absence of structural heart abnormalities [171]. Since then, approximately 150 different $R Y R 2$ mutations 
have been associated with CPVT and pathogenic variants in RYR2 account for approximately $60 \%$ of individuals with clinical diagnosis of CPVT. Other less prevalent genes associated with CPVT are CASQ2, CALM2, CALM3, TRDN, and possibly ANK2, KCNJ2 and CALM1 (Figure 2). Altogether, these genes are responsible for an additional 5\% of cases. Anomalies in CASQ2, which encodes the calsequestrin 2 protein, cause the second most common type of CPVT as a result of increased calcium release from the sarcoplasmic reticulum. Pathogenic variants in CASQ2 are associated with an autosomal-dominant pattern of inheritance, causing a higher rate of SD than that observed with RYR2 mutations [172]. However, CASQ2 variants have also been reported to be associated with autosomal-recessive CPVT [173].

Calmodulin is a protein encoded by CALM1, CALM2 and CALM3 that is involved in the calcium-dependent ICa inactivation of the L-type Ca channel and stabilizes the ryanodine channel. Therefore, pathogenic variants in calmodulin may cause $\mathrm{Ca}^{2+}$ overload [174]. Pathogenic variants in CALM1 may demonstrate compromised calcium binding and an aberrant interaction with the $R Y R 2$ calmodulin-binding-domain peptide [175]. In addition, pathogenic variants in CALM2 also cause reduced $\mathrm{Ca}^{2+}$-binding affinity and can be associated with overlapping features of LQTS and CPVT. CALM3 has now been associated with CPVT and both CALM1 and CALM3 mutations evoke arrhythmogenic Ca disturbances via ryanodine receptor 2 dysregulation [176]. Candidate gene screening has implicated TRDN as an autosomal-recessive form of CPVT [177]. TRDN encodes the triadin protein, which connects calsequestrin to ryanodine receptor 2 and stabilizes the channel. Pathogenic variants in TRDN may result in a diastolic leak of $\mathrm{Ca}^{2+}$ and $\mathrm{Ca}^{2+}$ overload in the myocytes. Both KCNJ2 [178] and ANK2 [179] pathogenic variants are also reported in patients with exercise-induced bi-directional VT. Finally, a locus for a severe form of CPVT was mapped at chromosome 7p22-p14 (homozygous) in a family but the responsible gene has not been identified [180].

\section{Conclusions}

SCD remains a major cause of death, mainly in young populations. In the last few years, technological improvements in genetics have helped in both the diagnosis and prevention of SCD. To date, several genes have been implicated in ion channel diseases, but a large number of families remain without a recognized genetic cause. The primary challenges to SCD prevention are early identification of individuals at risk and clinical measures in asymptomatic individuals carrying a mutation, since the first manifestation of the disease can be SCD itself. In the future, comprehensive genotype-phenotype studies in large cohorts of families should be performed in order to clarify the genetic basis of SCD-related diseases as well as the adoption of personalized preventive therapies for the prevention of SCD. Close interaction between families and a team of specialists including cardiologists, geneticists, genetic counselors, and even psychologists will be crucial to the development of such therapies.

Acknowledgments: No grants covering open access have been received.

Author Contributions: Anna Fernández-Falgueras, Georgia Sarquella-Brugada and Oscar Campuzano wrote the manuscript. Josep Brugada, Ramon Brugada and Oscar Campuzano designed the study. All authors revised and approved the final version of the manuscript.

Conflicts of Interest: The authors declare no conflicts of interest.

\section{References}

1. De Luna, A.B.; Elosua, R. Sudden death. Rev. Esp. Cardiol. 2012, 65, 1039-1052.

2. Pachon, M.; Almendral, J. Sudden death: Managing the patient who survives. Heart 2011, 97, 1619-1625. [CrossRef] [PubMed]

3. Basso, C.; Carturan, E.; Pilichou, K.; Rizzo, S.; Corrado, D.; Thiene, G. Sudden cardiac death with normal heart: Molecular autopsy. Cardiovasc. Pathol. 2010, 19, 321-325. [CrossRef] [PubMed] 
4. Oliva, A.; Flores, J.; Merigioli, S.; LeDuc, L.; Benito, B.; Partemi, S.; Arzamendi, D.; Campuzano, O.; Leung, T.L.; Iglesias, A.; et al. Autopsy investigation and bayesian approach to coronary artery disease in victims of motor-vehicle accidents. Atherosclerosis 2011, 218, 28-32. [CrossRef] [PubMed]

5. Podrid, P.J.; Myerburg, R.J. Epidemiology and stratification of risk for sudden cardiac death. Clin. Cardiol. 2005, 28, I3-I11. [CrossRef] [PubMed]

6. Nichol, G.; Rumsfeld, J.; Eigel, B.; Abella, B.S.; Labarthe, D.; Hong, Y.; O'Connor, R.E.; Mosesso, V.N.; Berg, R.A.; Leeper, B.B.; et al. Essential features of designating out-of-hospital cardiac arrest as a reportable event: A scientific statement from the American Heart Association Emergency Cardiovascular Care Committee; Council on Cardiopulmonary, Perioperative, And Critical Care; Council on Cardiovascular Nursing; Council on Clinical Cardiology; and Quality of Care and Outcomes Research Interdisciplinary Working Group. Circulation 2008, 117, 2299-2308. [PubMed]

7. Chugh, S.S.; Senashova, O.; Watts, A.; Tran, P.T.; Zhou, Z.; Gong, Q.; Titus, J.L.; Hayflick, S.J. Postmortem molecular screening in unexplained sudden death. J. Am. Coll. Cardiol. 2004, 43, 1625-1629. [CrossRef] [PubMed]

8. De Vreede-Swagemakers, J.J.; Gorgels, A.P.; Dubois-Arbouw, W.I.; van Ree, J.W.; Daemen, M.J.; Houben, L.G.; Wellens, H.J. Out-of-hospital cardiac arrest in the 1990's: A population-based study in the maastricht area on incidence, characteristics and survival. J. Am. Coll. Cardiol. 1997, 30, 1500-1505. [CrossRef]

9. Byrne, R.; Constant, O.; Smyth, Y.; Callagy, G.; Nash, P.; Daly, K.; Crowley, J. Multiple source surveillance incidence and aetiology of out-of-hospital sudden cardiac death in a rural population in the West of Ireland. Eur. Heart J. 2008, 29, 1418-1423. [CrossRef] [PubMed]

10. Hua, W.; Zhang, L.F.; Wu, Y.F.; Liu, X.Q.; Guo, D.S.; Zhou, H.L.; Gou, Z.P.; Zhao, L.C.; Niu, H.X.; Chen, K.P.; et al. Incidence of sudden cardiac death in China: Analysis of 4 regional populations. J. Am. Coll. Cardiol. 2009, 54, 1110-1118. [CrossRef] [PubMed]

11. Eckart, R.E.; Shry, E.A.; Burke, A.P.; McNear, J.A.; Appel, D.A.; Castillo-Rojas, L.M.; Avedissian, L.; Pearse, L.A.; Potter, R.N.; Tremaine, L.; et al. Sudden death in young adults: An autopsy-based series of a population undergoing active surveillance. J. Am. Coll. Cardiol. 2011, 58, 1254-1261. [CrossRef] [PubMed]

12. Fishman, G.I.; Chugh, S.S.; Dimarco, J.P.; Albert, C.M.; Anderson, M.E.; Bonow, R.O.; Buxton, A.E.; Chen, P.S.; Estes, M.; Jouven, X.; et al. Sudden cardiac death prediction and prevention: Report from a National Heart, Lung, And Blood Institute And Heart Rhythm Society Workshop. Circulation 2010, 122, 2335-2348. [CrossRef] [PubMed]

13. Myerburg, R.J.; Junttila, M.J. Sudden cardiac death caused by coronary heart disease. Circulation 2012, 125, 1043-1052. [CrossRef] [PubMed]

14. Arzamendi, D.; Benito, B.; Tizon-Marcos, H.; Flores, J.; Tanguay, J.F.; Ly, H.; Doucet, S.; Leduc, L.; Leung, T.K.; Campuzano, O.; et al. Increase in sudden death from coronary artery disease in young adults. Am. Heart J. 2011, 161, 574-580. [CrossRef] [PubMed]

15. Boczek, N.J.; Tester, D.J.; Ackerman, M.J. The molecular autopsy: An indispensable step following sudden cardiac death in the young? Herzschrittmacherther. Elektrophysiol. 2012, 23, 167-173. [CrossRef] [PubMed]

16. Campuzano, O.; Sanchez-Molero, O.; Allegue, C.; Coll, M.; Mademont-Soler, I.; Selga, E.; Ferrer-Costa, C.; Mates, J.; Iglesias, A.; Sarquella-Brugada, G.; et al. Post-mortem genetic analysis in juvenile cases of sudden cardiac death. Forensic. Sci. Int. 2014, 245, 30-37. [CrossRef] [PubMed]

17. Campuzano, O.; Allegue, C.; Partemi, S.; Iglesias, A.; Oliva, A.; Brugada, R. Negative autopsy and sudden cardiac death. Int. J. Leg. Med. 2014, 128, 599-606. [CrossRef] [PubMed]

18. Nerbonne, J.M.; Kass, R.S. Molecular physiology of cardiac repolarization. Physiol. Rev. 2005, 85, 1205-1253. [CrossRef] [PubMed]

19. Roden, D.M.; Balser, J.R.; George, A.L., Jr.; Anderson, M.E. Cardiac ion channels. Annu. Rev. Physiol. 2002, 64, 431-475. [CrossRef] [PubMed]

20. Amin, A.S.; Asghari-Roodsari, A.; Tan, H.L. Cardiac sodium channelopathies. Pflugers Arch. 2010, 460, 223-237. [CrossRef] [PubMed]

21. Antzelevitch, C.; Brugada, P.; Borggrefe, M.; Brugada, J.; Brugada, R.; Corrado, D.; Gussak, I.; LeMarec, H.; Nademanee, K.; Perez Riera, A.R.; et al. Brugada syndrome: Report of the second consensus conference. Heart Rhythm 2005, 2, 429-440. [CrossRef] [PubMed]

22. Berne, P.; Brugada, J. Brugada syndrome 2012. Circ. J. 2012, 76, 1563-1571. [CrossRef] [PubMed] 
23. Brugada, R.; Campuzano, O.; Sarquella-Brugada, G.; Brugada, J.; Brugada, P. Brugada syndrome. Methodist Debakey Cardiovasc J. 2014, 10, 25-28. [CrossRef] [PubMed]

24. Coronel, R.; Casini, S.; Koopmann, T.T.; Wilms-Schopman, F.J.; Verkerk, A.O.; de Groot, J.R.; Bhuiyan, Z.; Bezzina, C.R.; Veldkamp, M.W.; Linnenbank, A.C.; et al. Right ventricular fibrosis and conduction delay in a patient with clinical signs of Brugada syndrome: A combined electrophysiological, genetic, histopathologic, and computational study. Circulation 2005, 112, 2769-2777. [CrossRef] [PubMed]

25. Frustaci, A.; Russo, M.A.; Chimenti, C. Structural myocardial abnormalities in asymptomatic family members with Brugada syndrome and SCN5A gene mutation. Eur. Heart J. 2009. [CrossRef] [PubMed]

26. Wilde, A.A.; Antzelevitch, C.; Borggrefe, M.; Brugada, J.; Brugada, R.; Brugada, P.; Corrado, D.; Hauer, R.N.; Kass, R.S.; Nademanee, K.; et al. Proposed diagnostic criteria for the brugada syndrome: Consensus report. Circulation 2002, 106, 2514-2519. [CrossRef] [PubMed]

27. Priori, S.G.; Wilde, A.A.; Horie, M.; Cho, Y.; Behr, E.R.; Berul, C.; Blom, N.; Brugada, J.; Chiang, C.E.; Huikuri, H.; et al. HRS/EHRA/APHRS expert consensus statement on the diagnosis and management of patients with inherited primary arrhythmia syndromes: Document endorsed by HRS, EHRA, and APHRS in May 2013 and by ACCF, AHA, PACES, and AEPC in June 2013. Heart Rhythm 2013, 10, 1932-1963. [CrossRef] [PubMed]

28. Chen, Q.; Kirsch, G.E.; Zhang, D.; Brugada, R.; Brugada, J.; Brugada, P.; Potenza, D.; Moya, A.; Borggrefe, M.; Breithardt, G.; et al. Genetic basis and molecular mechanism for idiopathic ventricular fibrillation. Nature 1998, 392, 293-296. [PubMed]

29. Brugada, P.; Brugada, J.; Roy, D. Brugada syndrome 1992-2012: 20 years of scientific excitement, and more. Eur. Heart J. 2013, 34, 3610-3615. [CrossRef] [PubMed]

30. Watanabe, H.; Koopmann, T.T.; Le Scouarnec, S.; Yang, T.; Ingram, C.R.; Schott, J.J.; Demolombe, S.; Probst, V.; Anselme, F.; Escande, D.; et al. Sodium channel beta1 subunit mutations associated with brugada syndrome and cardiac conduction disease in humans. J. Clin. Investig. 2008, 118, 2260-2268. [PubMed]

31. Riuro, H.; Beltran-Alvarez, P.; Tarradas, A.; Selga, E.; Campuzano, O.; Verges, M.; Pagans, S.; Iglesias, A.; Brugada, J.; Brugada, P.; et al. A missense mutation in the sodium channel beta2 subunit reveals SCN2B as a new candidate gene for brugada syndrome. Hum. Mutat. 2013, 34, 961-966. [CrossRef] [PubMed]

32. Hu, D.; Barajas-Martinez, H.; Burashnikov, E.; Springer, M.; Wu, Y.; Varro, A.; Pfeiffer, R.; Koopmann, T.T.; Cordeiro, J.M.; Guerchicoff, A.; et al. A mutation in the beta 3 subunit of the cardiac sodium channel associated with Brugada ECG phenotype. Circ. Cardiovasc. Genet. 2009, 2, 270-278. [CrossRef] [PubMed]

33. Hu, D.; Barajas-Martinez, H.; Pfeiffer, R.; Dezi, F.; Pfeiffer, J.; Buch, T.; Betzenhauser, M.J.; Belardinelli, L.; Kahlig, K.M.; Rajamani, S.; et al. Mutations in SCN10A are responsible for a large fraction of cases of Brugada syndrome. J. Am. Coll. Cardiol. 2014, 64, 66-79. [CrossRef] [PubMed]

34. Behr, E.R.; Savio-Galimberti, E.; Barc, J.; Holst, A.G.; Petropoulou, E.; Prins, B.P.; Jabbari, J.; Torchio, M.; Berthet, M.; Mizusawa, Y.; et al. Role of common and rare variants in SCN10A: Results from the Brugada syndrome qrs locus gene discovery collaborative study. Cardiovasc. Res. 2015, 106, 520-529. [CrossRef] [PubMed]

35. Le Scouarnec, S.; Karakachoff, M.; Gourraud, J.B.; Lindenbaum, P.; Bonnaud, S.; Portero, V.; Duboscq-Bidot, L.; Daumy, X.; Simonet, F.; Teusan, R.; et al. Testing the burden of rare variation in arrhythmia-susceptibility genes provides new insights into molecular diagnosis for Brugada syndrome. Hum. Mol. Genet. 2015, 24, 2757-2763. [CrossRef] [PubMed]

36. Fukuyama, M.; Ohno, S.; Makiyama, T.; Horie, M. Novel SCN10A variants associated with Brugada syndrome. Europace 2016, 18, 905-911. [CrossRef] [PubMed]

37. Antzelevitch, C.; Pollevick, G.D.; Cordeiro, J.M.; Casis, O.; Sanguinetti, M.C.; Aizawa, Y.; Guerchicoff, A.; Pfeiffer, R.; Oliva, A.; Wollnik, B.; et al. Loss-of-function mutations in the cardiac calcium channel underlie a new clinical entity characterized by st-segment elevation, short QT intervals, and sudden cardiac death. Circulation 2007, 115, 442-449. [CrossRef] [PubMed]

38. Cordeiro, J.M.; Marieb, M.; Pfeiffer, R.; Calloe, K.; Burashnikov, E.; Antzelevitch, C. Accelerated inactivation of the l-type calcium current due to a mutation in CACNB2B underlies Brugada syndrome. J. Mol. Cell Cardiol. 2009, 46, 695-703. [CrossRef] [PubMed] 
39. Burashnikov, E.; Pfeiffer, R.; Barajas-Martinez, H.; Delpon, E.; Hu, D.; Desai, M.; Borggrefe, M.; Haissaguerre, M.; Kanter, R.; Pollevick, G.D.; et al. Mutations in the cardiac l-type calcium channel associated with inherited j-wave syndromes and sudden cardiac death. Heart Rhythm 2010, 7, 1872-1882. [CrossRef] [PubMed]

40. Giudicessi, J.R.; Ye, D.; Tester, D.J.; Crotti, L.; Mugione, A.; Nesterenko, V.V.; Albertson, R.M.; Antzelevitch, C.; Schwartz, P.J.; Ackerman, M.J. Transient outward current $\left(\mathrm{I}_{\mathrm{to}}\right)$ gain-of-function mutations in the KCND3-encoded Kv4.3 potassium channel and Brugada syndrome. Heart Rhythm 2011, 8, 1024-1032. [CrossRef] [PubMed]

41. Perrin, M.J.; Adler, A.; Green, S.; Al-Zoughool, F.; Doroshenko, P.; Orr, N.; Uppal, S.; Healey, J.S.; Birnie, D.; Sanatani, S.; et al. Evaluation of genes encoding for the transient outward current $\left(\mathrm{I}_{\mathrm{to}}\right)$ identifies the KCND2 gene as a cause of J-wave syndrome associated with sudden cardiac death. Circ. Cardiovasc. Genet. 2014, 7, 782-789. [CrossRef] [PubMed]

42. Delpon, E.; Cordeiro, J.M.; Nunez, L.; Thomsen, P.E.; Guerchicoff, A.; Pollevick, G.D.; Wu, Y.; Kanters, J.K.; Larsen, C.T.; Hofman-Bang, J.; et al. Functional effects of KCNE3 mutation and its role in the development of Brugada syndrome. Circ. Arrhythm. Electrophysiol. 2008, 1, 209-218. [CrossRef] [PubMed]

43. Ohno, S.; Zankov, D.P.; Ding, W.G.; Itoh, H.; Makiyama, T.; Doi, T.; Shizuta, S.; Hattori, T.; Miyamoto, A.; Naiki, N.; et al. KCNE5 (KCNE1L) variants are novel modulators of Brugada syndrome and idiopathic ventricular fibrillation. Circ. Arrhythm. Electrophysiol. 2011, 4, 352-361. [CrossRef] [PubMed]

44. Barajas-Martinez, H.; Hu, D.; Ferrer, T.; Onetti, C.G.; Wu, Y.; Burashnikov, E.; Boyle, M.; Surman, T.; Urrutia, J.; Veltmann, C.; et al. Molecular genetic and functional association of Brugada and early repolarization syndromes with S4221 missense mutation in KCNJ8. Heart Rhythm 2012, 9, 548-555. [CrossRef]

45. Kawamura, M.; Ozawa, T.; Yao, T.; Ashihara, T.; Sugimoto, Y.; Yagi, T.; Itoh, H.; Ito, M.; Makiyama, T.; Horie, M. Dynamic change in ST-segment and spontaneous occurrence of ventricular fibrillation in Brugada syndrome with a novel nonsense mutation in the SCN5A gene during long-term follow-up. Circ. J. 2009, 73, 584-588. [CrossRef] [PubMed]

46. Wang, Q.; Ohno, S.; Ding, W.G.; Fukuyama, M.; Miyamoto, A.; Itoh, H.; Makiyama, T.; Wu, J.; Bai, J.; Hasegawa, K.; et al. Gain-of-function KCNH2 mutations in patients with Brugada syndrome. J. Cardiovasc. Electrophysiol. 2014, 25, 522-530. [CrossRef] [PubMed]

47. Kattygnarath, D.; Maugenre, S.; Neyroud, N.; Balse, E.; Ichai, C.; Denjoy, I.; Dilanian, G.; Martins, R.P.; Fressart, V.; Berthet, M.; et al. Mog1: A new susceptibility gene for Brugada syndrome. Circ. Cardiovasc. Genet. 2011, 4, 261-268. [CrossRef] [PubMed]

48. Shy, D.; Gillet, L.; Abriel, H. Cardiac sodium channel NaV1.5 distribution in myocytes via interacting proteins: The multiple pool model. Biochim. Biophys. Acta 2013, 1833, 886-894. [CrossRef] [PubMed]

49. London, B.; Michalec, M.; Mehdi, H.; Zhu, X.; Kerchner, L.; Sanyal, S.; Viswanathan, P.C.; Pfahnl, A.E.; Shang, L.L.; Madhusudanan, M.; et al. Mutation in glycerol-3-phosphate dehydrogenase 1 like gene (Gpd1-L) decreases cardiac $\mathrm{Na}^{+}$current and causes inherited arrhythmias. Circulation 2007, 116, 2260-2268. [CrossRef] [PubMed]

50. Ishikawa, T.; Sato, A.; Marcou, C.A.; Tester, D.J.; Ackerman, M.J.; Crotti, L.; Schwartz, P.J.; On, Y.K.; Park, J.E.; Nakamura, K.; et al. A novel disease gene for Brugada syndrome: Sarcolemmal membrane-associated protein gene mutations impair intracellular trafficking of hNav1.5. Circ. Arrhythm. Electrophysiol. 2012, 5, 1098-1107. [CrossRef] [PubMed]

51. Cerrone, M.; Delmar, M. Desmosomes and the sodium channel complex: Implications for arrhythmogenic cardiomyopathy and Brugada syndrome. Trends Cardiovasc. Med. 2014, 24, 184-190. [CrossRef] [PubMed]

52. Cerrone, M.; Lin, X.; Zhang, M.; Agullo-Pascual, E.; Pfenniger, A.; Chkourko Gusky, H.; Novelli, V.; Kim, C.; Tirasawadichai, T.; Judge, D.P.; et al. Missense mutations in plakophilin-2 cause sodium current deficit and associate with a Brugada syndrome phenotype. Circulation 2014, 129, 1092-1103. [CrossRef] [PubMed]

53. Liu, H.; Chatel, S.; Simard, C.; Syam, N.; Salle, L.; Probst, V.; Morel, J.; Millat, G.; Lopez, M.; Abriel, H.; et al. Molecular genetics and functional anomalies in a series of 248 Brugada cases with 11 mutations in the trpm4 channel. PLoS ONE 2013, 8, e54131. [CrossRef] [PubMed]

54. Hennessey, J.A.; Marcou, C.A.; Wang, C.; Wei, E.Q.; Tester, D.J.; Torchio, M.; Dagradi, F.; Crotti, L.; Schwartz, P.J.; Ackerman, M.J.; et al. FGF12 is a candidate Brugada syndrome locus. Heart Rhythm 2013, 10, 1886-1894. [CrossRef] [PubMed] 
55. Bezzina, C.R.; Barc, J.; Mizusawa, Y.; Remme, C.A.; Gourraud, J.B.; Simonet, F.; Verkerk, A.O.; Schwartz, P.J.; Crotti, L.; Dagradi, F.; et al. Common variants at SCN5A-SCN10A and HEY2 are associated with Brugada syndrome, a rare disease with high risk of sudden cardiac death. Nat. Genet. 2013, 45, 1044-1049. [CrossRef] [PubMed]

56. Ueda, K.; Hirano, Y.; Higashiuesato, Y.; Aizawa, Y.; Hayashi, T.; Inagaki, N.; Tana, T.; Ohya, Y.; Takishita, S.; Muratani, H.; et al. Role of HCN4 channel in preventing ventricular arrhythmia. J. Hum. Genet. 2009, 54, 115-121. [CrossRef] [PubMed]

57. Boczek, N.J.; Ye, D.; Johnson, E.K.; Wang, W.; Crotti, L.; Tester, D.J.; Dagradi, F.; Mizusawa, Y.; Torchio, M.; Alders, M.; et al. Characterization of SEMA3A-encoded semaphorin as a naturally occurring kv4.3 protein inhibitor and its contribution to Brugada syndrome. Circ. Res. 2014, 115, 460-469. [CrossRef] [PubMed]

58. Eastaugh, L.J.; James, P.A.; Phelan, D.G.; Davis, A.M. Brugada syndrome caused by a large deletion in SCN5A only detected by multiplex ligation-dependent probe amplification. J. Cardiovasc. Electrophysiol. 2011, 22, 1073-1076. [CrossRef] [PubMed]

59. Mademont-Soler, I.; Pinsach-Abuin, M.L.; Riuro, H.; Mates, J.; Perez-Serra, A.; Coll, M.; Porres, J.M.; Del Olmo, B.; Iglesias, A.; Selga, E.; et al. Large genomic imbalances in Brugada syndrome. PLoS ONE 2016, 11, e0163514. [CrossRef] [PubMed]

60. Garcia-Molina, E.; Lacunza, J.; Ruiz-Espejo, F.; Sabater, M.; Garcia-Alberola, A.; Gimeno, J.R.; Canizares, F.; Garcia, A.; Martinez, P.; Valdes, M.; et al. A study of the SCN5A gene in a cohort of 76 patients with Brugada syndrome. Clin. Genet. 2013, 83, 530-538. [CrossRef] [PubMed]

61. Koopmann, T.T.; Beekman, L.; Alders, M.; Meregalli, P.G.; Mannens, M.M.; Moorman, A.F.; Wilde, A.A.; Bezzina, C.R. Exclusion of multiple candidate genes and large genomic rearrangements in SCN5A in a dutch Brugada syndrome cohort. Heart Rhythm 2007, 4, 752-755. [CrossRef] [PubMed]

62. Selga, E.; Campuzano, O.; Pinsach-Abuin, M.L.; Perez-Serra, A.; Mademont-Soler, I.; Riuro, H.; Pico, F.; Coll, M.; Iglesias, A.; Pagans, S.; et al. Comprehensive genetic characterization of a spanish Brugada syndrome cohort. PLoS ONE 2015, 10, e0132888. [CrossRef] [PubMed]

63. Kapplinger, J.D.; Tester, D.J.; Alders, M.; Benito, B.; Berthet, M.; Brugada, J.; Brugada, P.; Fressart, V.; Guerchicoff, A.; Harris-Kerr, C.; et al. An international compendium of mutations in the SCN5A-encoded cardiac sodium channel in patients referred for Brugada syndrome genetic testing. Heart Rhythm 2010, 7 , 33-46. [CrossRef] [PubMed]

64. Wilde, A.A.; Postema, P.G.; Di Diego, J.M.; Viskin, S.; Morita, H.; Fish, J.M.; Antzelevitch, C. The pathophysiological mechanism underlying Brugada syndrome: Depolarization versus repolarization. J. Mol. Cell Cardiol. 2010, 49, 543-553. [CrossRef] [PubMed]

65. Priori, S.G.; Blomstrom-Lundqvist, C.; Mazzanti, A.; Blom, N.; Borggrefe, M.; Camm, J.; Elliott, P.M.; Fitzsimons, D.; Hatala, R.; Hindricks, G.; et al. 2015 ESC guidelines for the management of patients with ventricular arrhythmias and the prevention of sudden cardiac death. Rev. Esp. Cardiol. 2016. [CrossRef] [PubMed]

66. Jervell, A.; Lange-Nielsen, F. Congenital deaf-mutism, functional heart disease with prolongation of the QT interval and sudden death. Am. Heart J. 1957, 54, 59-68. [CrossRef]

67. Levine, S.A.; Woodworth, C.R. Congenital deaf-mutism, prolonged qt interval, syncopal attacks and sudden death. N. Engl. J. Med. 1958, 259, 412-417. [CrossRef] [PubMed]

68. Romano, C.; Gemme, G.; Pongiglione, R. Rare cardiac arrythmias of the pediatric age. II. Syncopal attacks due to paroxysmal ventricular fibrillation. (presentation of 1st case in italian pediatric literature). Clin. Pediatr. 1963, 45, 656-683.

69. Ward, O.C. A new familial cardiac syndrome in children. J. Ir. Med. Assoc. 1964, 54, 103-106. [PubMed]

70. Schwartz, P.J.; Periti, M.; Malliani, A. The long QT syndrome. Am. Heart J. 1975, 89, 378-390. [CrossRef]

71. Kaufman, E.S. Arrhythmic risk in congenital long QT syndrome. J. Electrocardiol. 2011, 44, 645-649. [CrossRef] [PubMed]

72. Schwartz, P.J.; Stramba-Badiale, M.; Crotti, L.; Pedrazzini, M.; Besana, A.; Bosi, G.; Gabbarini, F.; Goulene, K.; Insolia, R.; Mannarino, S.; et al. Prevalence of the congenital long-QT syndrome. Circulation 2009, 120, 1761-1767. [CrossRef] [PubMed]

73. Rautaharju, P.M.; Zhou, S.H.; Wong, S.; Calhoun, H.P.; Berenson, G.S.; Prineas, R.; Davignon, A. Sex differences in the evolution of the electrocardiographic qt interval with age. Can. J. Cardiol. 1992, 8, 690-695. [PubMed] 
74. Hashiba, K. Sex differences in phenotypic manifestation and gene transmission in the romano-ward syndrome. Ann. N. Y. Acad. Sci. 1992, 644, 142-156. [CrossRef] [PubMed]

75. Lehmann, M.H.; Timothy, K.W.; Frankovich, D.; Fromm, B.S.; Keating, M.; Locati, E.H.; Taggart, R.T.; Towbin, J.A.; Moss, A.J.; Schwartz, P.J.; et al. Age-gender influence on the rate-corrected qt interval and the qt-heart rate relation in families with genotypically characterized long QT syndrome. J. Am. Coll. Cardiol. 1997, 29, 93-99. [CrossRef]

76. Rodriguez, I.; Kilborn, M.J.; Liu, X.K.; Pezzullo, J.C.; Woosley, R.L. Drug-induced qt prolongation in women during the menstrual cycle. JAMA 2001, 285, 1322-1326. [CrossRef] [PubMed]

77. Locati, E.H.; Zareba, W.; Moss, A.J.; Schwartz, P.J.; Vincent, G.M.; Lehmann, M.H.; Towbin, J.A.; Priori, S.G.; Napolitano, C.; Robinson, J.L.; et al. Age- and sex-related differences in clinical manifestations in patients with congenital long-QT syndrome: Findings from the international lqts registry. Circulation 1998, 97, 2237-2244. [CrossRef] [PubMed]

78. Seth, R.; Moss, A.J.; McNitt, S.; Zareba, W.; Andrews, M.L.; Qi, M.; Robinson, J.L.; Goldenberg, I.; Ackerman, M.J.; Benhorin, J.; et al. Long QT syndrome and pregnancy. J. Am. Coll Cardiol. 2007, 49, 1092-1098. [CrossRef] [PubMed]

79. Makkar, R.R.; Fromm, B.S.; Steinman, R.T.; Meissner, M.D.; Lehmann, M.H. Female gender as a risk factor for torsades de pointes associated with cardiovascular drugs. JAMA 1993, 270, 2590-2597. [CrossRef] [PubMed]

80. Lehmann, M.H.; Hardy, S.; Archibald, D.; quart, B.; MacNeil, D.J. Sex difference in risk of torsade de pointes with d,1-sotalol. Circulation 1996, 94, 2535-2541. [CrossRef] [PubMed]

81. Pratt, C.M.; Waldo, A.L.; Camm, A.J. Can antiarrhythmic drugs survive survival trials? Am. J. Cardiol. 1998, 81, 24D-34D. [CrossRef]

82. Medeiros-Domingo, A.; Iturralde-Torres, P.; Ackerman, M.J. Clinical and genetic characteristics of long QT syndrome. Rev. Esp. Cardiol. 2007, 60, 739-752. [CrossRef] [PubMed]

83. Roden, D.M. Cellular basis of drug-induced torsades de pointes. Br. J. Pharmacol. 2008, 154, $1502-1507$. [CrossRef] [PubMed]

84. Roden, D.M. Clinical practice. Long-QT syndrome. N. Engl. J. Med. 2008, 358, 169-176. [CrossRef] [PubMed]

85. Morita, H.; Wu, J.; Zipes, D.P. The QT syndromes: Long and short. Lancet 2008, 372, 750-763. [CrossRef]

86. Goldenberg, I.; Zareba, W.; Moss, A.J. Long QT syndrome. Curr. Probl. Cardiol. 2008, 33, 629-694. [CrossRef] [PubMed]

87. Vohra, J. The long QT syndrome. Heart Lung Circ. 2007, 16, S5-S12. [CrossRef] [PubMed]

88. Brink, P.A.; Crotti, L.; Corfield, V.; Goosen, A.; Durrheim, G.; Hedley, P.; Heradien, M.; Geldenhuys, G.; Vanoli, E.; Bacchini, S.; et al. Phenotypic variability and unusual clinical severity of congenital long-QT syndrome in a founder population. Circulation 2005, 112, 2602-2610. [CrossRef] [PubMed]

89. Priori, S.G.; Napolitano, C.; Vicentini, A. Inherited arrhythmia syndromes: Applying the molecular biology and genetic to the clinical management. J. Interv. Card. Electrophysiol. 2003, 9, 93-101. [CrossRef] [PubMed]

90. Moss, A.J.; Schwartz, P.J.; Crampton, R.S.; Tzivoni, D.; Locati, E.H.; MacCluer, J.; Hall, W.J.; Weitkamp, L.; Vincent, G.M.; Garson, A., Jr.; et al. The long qt syndrome. Prospective longitudinal study of 328 families. Circulation 1991, 84, 1136-1144. [CrossRef] [PubMed]

91. Schwartz, P.J. Idiopathic long QT syndrome: Progress and questions. Am. Heart. J. 1985, 109, $399-411$. [CrossRef]

92. Schwartz, P.J.; Moss, A.J.; Vincent, G.M.; Crampton, R.S. Diagnostic criteria for the long QT syndrome. An update. Circulation 1993, 88, 782-784. [CrossRef] [PubMed]

93. Schwartz, P.J. The congenital long QT syndromes from genotype to phenotype: Clinical implications. J. Intern. Med. 2006, 259, 39-47. [CrossRef] [PubMed]

94. Schwartz, P.J. Practical issues in the management of the long qt syndrome: Focus on diagnosis and therapy. Swiss Med. Wkly. 2013. [CrossRef] [PubMed]

95. Zhang, L.; Timothy, K.W.; Vincent, G.M.; Lehmann, M.H.; Fox, J.; Giuli, L.C.; Shen, J.; Splawski, I.; Priori, S.G.; Compton, S.J.; et al. Spectrum of ST-T-wave patterns and repolarization parameters in congenital long-QT syndrome: Ecg findings identify genotypes. Circulation 2000, 102, 2849-2855. [CrossRef] [PubMed]

96. Moss, A.J.; Zareba, W.; Benhorin, J.; Locati, E.H.; Hall, W.J.; Robinson, J.L.; Schwartz, P.J.; Towbin, J.A.; Vincent, G.M.; Lehmann, M.H. ECG T-wave patterns in genetically distinct forms of the hereditary long QT syndrome. Circulation 1995, 92, 2929-2934. [CrossRef] [PubMed] 
97. Zhang, L.; Benson, D.W.; Tristani-Firouzi, M.; Ptacek, L.J.; Tawil, R.; Schwartz, P.J.; George, A.L.; Horie, M.; Andelfinger, G.; Snow, G.L.; et al. Electrocardiographic features in andersen-tawil syndrome patients with kcnj2 mutations: Characteristic T-U-wave patterns predict the KCNJ2 genotype. Circulation 2005, 111, 2720-2726. [CrossRef] [PubMed]

98. Lupoglazoff, J.M.; Denjoy, I.; Villain, E.; Fressart, V.; Simon, F.; Bozio, A.; Berthet, M.; Benammar, N.; Hainque, B.; Guicheney, P. Long QT syndrome in neonates: Conduction disorders associated with herg mutations and sinus bradycardia with KCNQ1 mutations. J. Am. Coll. Cardiol. 2004, 43, 826-830. [CrossRef] [PubMed]

99. Donger, C.; Denjoy, I.; Berthet, M.; Neyroud, N.; Cruaud, C.; Bennaceur, M.; Chivoret, G.; Schwartz, K.; Coumel, P.; Guicheney, P. KVLQT1 c-terminal missense mutation causes a forme fruste long-QT syndrome. Circulation 1997, 96, 2778-2781. [CrossRef] [PubMed]

100. Paulussen, A.D.; Gilissen, R.A.; Armstrong, M.; Doevendans, P.A.; Verhasselt, P.; Smeets, H.J.; Schulze-Bahr, E.; Haverkamp, W.; Breithardt, G.; Cohen, N.; et al. Genetic variations of KCNQ1, KCNH2, SCN5A, KCNE1, and KCNE2 in drug-induced long qt syndrome patients. J. Mol. Med. 2004, 82, $182-188$. [CrossRef] [PubMed]

101. Schwartz, P.J.; Malliani, A. Electrical alternation of the T-wave: Clinical and experimental evidence of its relationship with the sympathetic nervous system and with the long Q-T syndrome. Am. Heart J. 1975, 89, 45-50. [CrossRef]

102. Keating, M.; Atkinson, D.; Dunn, C.; Timothy, K.; Vincent, G.M.; Leppert, M. Linkage of a cardiac arrhythmia, the long QT syndrome, and the harvey RAS-1 gene. Science 1991, 252, 704-706. [CrossRef] [PubMed]

103. Towbin, J.A. Molecular genetic aspects of the romano-ward long QT syndrome. Tex. Heart Inst. J. 1994, 21, 42-47. [PubMed]

104. Towbin, J.A.; Li, H.; Taggart, R.T.; Lehmann, M.H.; Schwartz, P.J.; Satler, C.A.; Ayyagari, R.; Robinson, J.L.; Moss, A.; Hejtmancik, J.F. Evidence of genetic heterogeneity in romano-ward long QT syndrome. Analysis of 23 families. Circulation 1994, 90, 2635-2644. [CrossRef] [PubMed]

105. Jiang, C.; Atkinson, D.; Towbin, J.A.; Splawski, I.; Lehmann, M.H.; Li, H.; Timothy, K.; Taggart, R.T.; Schwartz, P.J.; Vincent, G.M.; et al. Two long QT syndrome loci map to chromosomes 3 and 7 with evidence for further heterogeneity. Nat. Genet. 1994, 8, 141-147. [CrossRef] [PubMed]

106. Kapplinger, J.D.; Tester, D.J.; Salisbury, B.A.; Carr, J.L.; Harris-Kerr, C.; Pollevick, G.D.; Wilde, A.A.; Ackerman, M.J. Spectrum and prevalence of mutations from the first 2,500 consecutive unrelated patients referred for the familion long qt syndrome genetic test. Heart Rhythm 2009, 6, 1297-1303. [CrossRef] [PubMed]

107. Barhanin, J.; Lesage, F.; Guillemare, E.; Fink, M.; Lazdunski, M.; Romey, G. K(V)LQT1 and lsK (minK) proteins associate to form the I(Ks) cardiac potassium current. Nature 1996, 384, 78-80. [CrossRef] [PubMed]

108. Bellocq, C.; van Ginneken, A.C.; Bezzina, C.R.; Alders, M.; Escande, D.; Mannens, M.M.; Baro, I.; Wilde, A.A. Mutation in the KCNQ1 gene leading to the short QT-interval syndrome. Circulation 2004, 109, 2394-2397. [CrossRef] [PubMed]

109. Wang, Q.; Curran, M.E.; Splawski, I.; Burn, T.C.; Millholland, J.M.; VanRaay, T.J.; Shen, J.; Timothy, K.W.; Vincent, G.M.; de Jager, T.; et al. Positional cloning of a novel potassium channel gene: KVLQT1 mutations cause cardiac arrhythmias. Nat. Genet. 1996, 12, 17-23. [CrossRef]

110. Curran, M.E.; Splawski, I.; Timothy, K.W.; Vincent, G.M.; Green, E.D.; Keating, M.T. A molecular basis for cardiac arrhythmia: Herg mutations cause long QT syndrome. Cell 1995, 80, 795-803. [CrossRef]

111. Wang, Q.; Shen, J.; Splawski, I.; Atkinson, D.; Li, Z.; Robinson, J.L.; Moss, A.J.; Towbin, J.A.; Keating, M.T. SCN5A mutations associated with an inherited cardiac arrhythmia, long qt syndrome. Cell 1995, 80, 805-811. [CrossRef]

112. Mohler, P.J.; Schott, J.J.; Gramolini, A.O.; Dilly, K.W.; Guatimosim, S.; duBell, W.H.; Song, L.S.; Haurogne, K.; Kyndt, F.; Ali, M.E.; et al. Ankyrin-b mutation causes type 4 long-QT cardiac arrhythmia and sudden cardiac death. Nature 2003, 421, 634-639. [CrossRef] [PubMed]

113. Splawski, I.; Tristani-Firouzi, M.; Lehmann, M.H.; Sanguinetti, M.C.; Keating, M.T. Mutations in the hmink gene cause long QT syndrome and suppress iks function. Nat. Genet. 1997, 17, 338-340. [CrossRef] [PubMed]

114. Abbott, G.W.; Sesti, F.; Splawski, I.; Buck, M.E.; Lehmann, M.H.; Timothy, K.W.; Keating, M.T.; Goldstein, S.A. MIRP1 forms IKR potassium channels with HERG and is associated with cardiac arrhythmia. Cell 1999, 97, 175-187. [CrossRef] 
115. Andersen, E.D.; Krasilnikoff, P.A.; Overvad, H. Intermittent muscular weakness, extrasystoles, and multiple developmental anomalies: A new syndrome? Acta Paediatr. Scand. 1971, 60, 559-564. [CrossRef] [PubMed]

116. Tawil, R.; Ptacek, L.J.; Pavlakis, S.G.; DeVivo, D.C.; Penn, A.S.; Ozdemir, C.; Griggs, R.C. Andersen's syndrome: Potassium-sensitive periodic paralysis, ventricular ectopy, and dysmorphic features. Ann. Neurol. 1994, 35, 326-330. [CrossRef] [PubMed]

117. Boczek, N.J.; Best, J.M.; Tester, D.J.; Giudicessi, J.R.; Middha, S.; Evans, J.M.; Kamp, T.J.; Ackerman, M.J. Exome sequencing and systems biology converge to identify novel mutations in the l-type calcium channel, CACNA1C, linked to autosomal dominant long QT syndrome. Circ. Cardiovasc. Genet. 2013, 6, 279-289. [CrossRef] [PubMed]

118. Fukuyama, M.; Ohno, S.; Wang, Q.; Shirayama, T.; Itoh, H.; Horie, M. Nonsense-mediated mrna decay due to a CACNA1C splicing mutation in a patient with Brugada syndrome. Heart Rhythm 2014, 11, 629-634. [CrossRef] [PubMed]

119. Splawski, I.; Timothy, K.W.; Sharpe, L.M.; Decher, N.; Kumar, P.; Bloise, R.; Napolitano, C.; Schwartz, P.J.; Joseph, R.M.; Condouris, K.; et al. Ca(v)1.2 calcium channel dysfunction causes a multisystem disorder including arrhythmia and autism. Cell 2004, 119, 19-31. [CrossRef] [PubMed]

120. Splawski, I.; Timothy, K.W.; Decher, N.; Kumar, P.; Sachse, F.B.; Beggs, A.H.; Sanguinetti, M.C.; Keating, M.T. Severe arrhythmia disorder caused by cardiac L-type calcium channel mutations. Proc. Natl. Acad. Sci. USA 2005, 102, 8089-8096. [CrossRef] [PubMed]

121. Boczek, N.J.; Miller, E.M.; Ye, D.; Nesterenko, V.V.; Tester, D.J.; Antzelevitch, C.; Czosek, R.J.; Ackerman, M.J.; Ware, S.M. Novel timothy syndrome mutation leading to increase in CACNA1C window current. Heart Rhythm 2015, 12, 211-219. [CrossRef] [PubMed]

122. Vatta, M.; Ackerman, M.J.; Ye, B.; Makielski, J.C.; Ughanze, E.E.; Taylor, E.W.; Tester, D.J.; Balijepalli, R.C.; Foell, J.D.; Li, Z.; et al. Mutant caveolin-3 induces persistent late sodium current and is associated with long-QT syndrome. Circulation 2006, 114, 2104-2112. [CrossRef] [PubMed]

123. Medeiros-Domingo, A.; Kaku, T.; Tester, D.J.; Iturralde-Torres, P.; Itty, A.; Ye, B.; Valdivia, C.; Ueda, K.; Canizales-Quinteros, S.; Tusie-Luna, M.T.; et al. SCN4B-encoded sodium channel beta4 subunit in congenital long-QT syndrome. Circulation 2007, 116, 134-142. [CrossRef] [PubMed]

124. Ueda, K.; Valdivia, C.; Medeiros-Domingo, A.; Tester, D.J.; Vatta, M.; Farrugia, G.; Ackerman, M.J.; Makielski, J.C. Syntrophin mutation associated with long QT syndrome through activation of the nnos-SCN5A macromolecular complex. Proc. Natl. Acad. Sci. USA 2008, 105, 9355-9360. [CrossRef] [PubMed]

125. Chen, L.; Marquardt, M.L.; Tester, D.J.; Sampson, K.J.; Ackerman, M.J.; Kass, R.S. Mutation of an a-kinaseanchoring protein causes long-QT syndrome. Proc. Natl. Acad. Sci. USA 2007, 104, 20990-20995. [CrossRef] [PubMed]

126. Chen, M.X.; Sandow, S.L.; Doceul, V.; Chen, Y.H.; Harper, H.; Hamilton, B.; Meadows, H.J.; Trezise, D.J.; Clare, J.J. Improved functional expression of recombinant human ether-a-go-go (hERG) $\mathrm{k}^{+}$channels by cultivation at reduced temperature. BMC Biotechnol. 2007. [CrossRef] [PubMed]

127. Yang, Y.; Liang, B.; Liu, J.; Li, J.; Grunnet, M.; Olesen, S.P.; Rasmussen, H.B.; Ellinor, P.T.; Gao, L.; Lin, X.; et al. Identification of a KIR3.4 mutation in congenital long QT syndrome. Am. J. Hum. Genet. 2010, 86, 872-880. [CrossRef] [PubMed]

128. Crotti, L.; Johnson, C.N.; Graf, E.; De Ferrari, G.M.; Cuneo, B.F.; Ovadia, M.; Papagiannis, J.; Feldkamp, M.D.; Rathi, S.G.; Kunic, J.D.; et al. Calmodulin mutations associated with recurrent cardiac arrest in infants. Circulation 2013, 127, 1009-1017. [CrossRef] [PubMed]

129. Makita, N.; Yagihara, N.; Crotti, L.; Johnson, C.N.; Beckmann, B.M.; Roh, M.S.; Shigemizu, D.; Lichtner, P.; Ishikawa, T.; Aiba, T.; et al. Novel calmodulin mutations associated with congenital arrhythmia susceptibility. Circ. Cardiovasc. Genet. 2014, 7, 466-474. [CrossRef] [PubMed]

130. Reed, G.J.; Boczek, N.J.; Etheridge, S.P.; Ackerman, M.J. Calm3 mutation associated with long QT syndrome. Heart Rhythm 2015, 12, 419-422. [CrossRef] [PubMed]

131. Riuro, H.; Campuzano, O.; Arbelo, E.; Iglesias, A.; Batlle, M.; Perez-Villa, F.; Brugada, J.; Perez, G.J.; Scornik, F.S.; Brugada, R. A missense mutation in the sodium channel beta1b subunit reveals SCN1B as a susceptibility gene underlying long qt syndrome. Heart Rhythm 2014, 11, 1202-1209. [CrossRef] [PubMed] 
132. Kauferstein, S.; Kiehne, N.; Erkapic, D.; Schmidt, J.; Hamm, C.W.; Bratzke, H.; Pitschner, H.F.; Kuniss, M.; Neumann, T. A novel mutation in the cardiac ryanodine receptor gene (RYR2) in a patient with an unequivocal lqts. Int. J. Cardiol. 2011, 146, 249-250. [CrossRef] [PubMed]

133. Schwartz, P.J.; Spazzolini, C.; Crotti, L.; Bathen, J.; Amlie, J.P.; Timothy, K.; Shkolnikova, M.; Berul, C.I.; Bitner-Glindzicz, M.; Toivonen, L.; et al. The jervell and lange-nielsen syndrome: Natural history, molecular basis, and clinical outcome. Circulation 2006, 113, 783-790. [CrossRef] [PubMed]

134. Gussak, I.; Brugada, P.; Brugada, J.; Wright, R.S.; Kopecky, S.L.; Chaitman, B.R.; Bjerregaard, P. Idiopathic short QT interval: A new clinical syndrome? Cardiology 2000, 94, 99-102. [CrossRef] [PubMed]

135. Gaita, F.; Giustetto, C.; Bianchi, F.; Wolpert, C.; Schimpf, R.; Riccardi, R.; Grossi, S.; Richiardi, E.; Borggrefe, M. Short QT syndrome: A familial cause of sudden death. Circulation 2003, 108, 965-970. [CrossRef] [PubMed]

136. Mazzanti, A.; O’Rourke, S.; Ng, K.; Miceli, C.; Borio, G.; Curcio, A.; Esposito, F.; Napolitano, C.; Priori, S.G. The usual suspects in sudden cardiac death of the young: A focus on inherited arrhythmogenic diseases. Expert Rev. Cardiovasc. Ther. 2014, 12, 499-519. [CrossRef] [PubMed]

137. Kobza, R.; Roos, M.; Niggli, B.; Abacherli, R.; Lupi, G.A.; Frey, F.; Schmid, J.J.; Erne, P. Prevalence of long and short QT in a young population of 41,767 predominantly male swiss conscripts. Heart Rhythm 2009, 6, 652-657. [CrossRef] [PubMed]

138. Funada, A.; Hayashi, K.; Ino, H.; Fujino, N.; Uchiyama, K.; Sakata, K.; Masuta, E.; Sakamoto, Y.; Tsubokawa, T.; Yamagishi, M. Assessment of qt intervals and prevalence of short QT syndrome in japan. Clin. Cardiol. 2008, 31, 270-274. [CrossRef] [PubMed]

139. Anttonen, O.; Junttila, M.J.; Rissanen, H.; Reunanen, A.; Viitasalo, M.; Huikuri, H.V. Prevalence and prognostic significance of short qt interval in a middle-aged finnish population. Circulation 2007, 116, 714-720. [CrossRef] [PubMed]

140. Rudic, B.; Schimpf, R.; Borggrefe, M. Short qt syndrome-Review of diagnosis and treatment. Arrhythm. Electrophysiol. Rev. 2014, 3, 76-79. [CrossRef] [PubMed]

141. Miyamoto, A.; Hayashi, H.; Yoshino, T.; Kawaguchi, T.; Taniguchi, A.; Itoh, H.; Sugimoto, Y.; Itoh, M.; Makiyama, T.; Xue, J.Q.; et al. Clinical and electrocardiographic characteristics of patients with short qt interval in a large hospital-based population. Heart Rhythm 2012, 9, 66-74. [CrossRef] [PubMed]

142. Giustetto, C.; Di Monte, F.; Wolpert, C.; Borggrefe, M.; Schimpf, R.; Sbragia, P.; Leone, G.; Maury, P.; Anttonen, O.; Haissaguerre, M.; et al. Short qt syndrome: Clinical findings and diagnostic-therapeutic implications. Eur. Heart J. 2006, 27, 2440-2447. [CrossRef] [PubMed]

143. Nierenberg, D.W. Spironolactone and metabolic acidosis. Ann. Intern. Med. 1979, 91, 321-322. [CrossRef] [PubMed]

144. Holbrook, M.; Malik, M.; Shah, R.R.; Valentin, J.P. Drug induced shortening of the QT/QTC interval: An emerging safety issue warranting further modelling and evaluation in drug research and development? J. Pharmacol. Toxicol. Methods 2009, 59, 21-28. [CrossRef] [PubMed]

145. Viskin, S.; Justo, D.; Zeltser, D. Drug-induced prolongation of the QT interval. N. Engl. J. Med. 2004, 350, 2618-2621. [PubMed]

146. Viskin, S.; Zeltser, D.; Ish-Shalom, M.; Katz, A.; Glikson, M.; Justo, D.; Tekes-Manova, D.; Belhassen, B. Is idiopathic ventricular fibrillation a short QT syndrome? Comparison of qt intervals of patients with idiopathic ventricular fibrillation and healthy controls. Heart Rhythm 2004, 1, 587-591. [CrossRef] [PubMed]

147. Schimpf, R.; Wolpert, C.; Gaita, F.; Giustetto, C.; Borggrefe, M. Short QT syndrome. Cardiovasc. Res. 2005, 67, 357-366. [CrossRef] [PubMed]

148. Schimpf, R.; Borggrefe, M.; Wolpert, C. Clinical and molecular genetics of the short QT syndrome. Curr. Opin. Cardiol. 2008, 23, 192-198. [CrossRef] [PubMed]

149. Tulumen, E.; Giustetto, C.; Wolpert, C.; Maury, P.; Anttonen, O.; Probst, V.; Blanc, J.J.; Sbragia, P.; Scrocco, C.; Rudic, B.; et al. PQ segment depression in patients with short QT syndrome: A novel marker for diagnosing short qt syndrome? Heart Rhythm 2014, 11, 1024-1030. [CrossRef] [PubMed]

150. Borggrefe, M.; Wolpert, C.; Antzelevitch, C.; Veltmann, C.; Giustetto, C.; Gaita, F.; Schimpf, R. Short QT syndrome. Genotype-phenotype correlations. J. Electrocardiol. 2005, 38, 75-80. [CrossRef] [PubMed]

151. Giustetto, C.; Schimpf, R.; Mazzanti, A.; Scrocco, C.; Maury, P.; Anttonen, O.; Probst, V.; Blanc, J.J.; Sbragia, P.; Dalmasso, P.; et al. Long-term follow-up of patients with short QT syndrome. J. Am. Coll. Cardiol. 2011, 58, 587-595. [CrossRef] 
152. Gollob, M.H.; Redpath, C.J.; Roberts, J.D. The short QT syndrome: Proposed diagnostic criteria. J. Am. Coll. Cardiol. 2011, 57, 802-812. [CrossRef] [PubMed]

153. Brugada, R.; Hong, K.; Dumaine, R.; Cordeiro, J.; Gaita, F.; Borggrefe, M.; Menendez, T.M.; Brugada, J.; Pollevick, G.D.; Wolpert, C.; et al. Sudden death associated with short-QT syndrome linked to mutations in herg. Circulation 2004, 109, 30-35. [CrossRef] [PubMed]

154. Priori, S.G.; Pandit, S.V.; Rivolta, I.; Berenfeld, O.; Ronchetti, E.; Dhamoon, A.; Napolitano, C.; Anumonwo, J.; di Barletta, M.R.; Gudapakkam, S.; et al. A novel form of short QT syndrome (SQT3) is caused by a mutation in the KCNJ2 gene. Circ. Res. 2005, 96, 800-807. [CrossRef] [PubMed]

155. Templin, C.; Ghadri, J.R.; Rougier, J.S.; Baumer, A.; Kaplan, V.; Albesa, M.; Sticht, H.; Rauch, A.; Puleo, C.; $\mathrm{Hu}, \mathrm{D}$; ; et al. Identification of a novel loss-of-function calcium channel gene mutation in short qt syndrome (SQTS6). Eur. Heart J. 2011, 32, 1077-1088. [CrossRef] [PubMed]

156. Berg, K.J. Multifocal ventricular extrasytoles with adams-stokes syndrome in siblings. Am. Heart J. 1960, 60, 965-970. [CrossRef]

157. Reid, D.S.; Tynan, M.; Braidwood, L.; Fitzgerald, G.R. Bidirectional tachycardia in a child. A study using his bundle electrography. Br. Heart J. 1975, 37, 339-344. [CrossRef] [PubMed]

158. Leenhardt, A.; Lucet, V.; Denjoy, I.; Grau, F.; Ngoc, D.D.; Coumel, P. Catecholaminergic polymorphic ventricular tachycardia in children. A 7-year follow-up of 21 patients. Circulation 1995, 91, 1512-1519. [CrossRef] [PubMed]

159. Lieve, K.V.; van der Werf, C.; Wilde, A.A. Catecholaminergic polymorphic ventricular tachycardia. Circ. J. 2016, 80, 1285-1291. [CrossRef] [PubMed]

160. Napolitano, C.; Priori, S.G. Diagnosis and treatment of catecholaminergic polymorphic ventricular tachycardia. Heart Rhythm 2007, 4, 675-678. [CrossRef] [PubMed]

161. Priori, S.G.; Napolitano, C.; Memmi, M.; Colombi, B.; Drago, F.; Gasparini, M.; DeSimone, L.; Coltorti, F.; Bloise, R.; Keegan, R.; et al. Clinical and molecular characterization of patients with catecholaminergic polymorphic ventricular tachycardia. Circulation 2002, 106, 69-74. [CrossRef] [PubMed]

162. Lehnart, S.E.; Wehrens, X.H.; Laitinen, P.J.; Reiken, S.R.; Deng, S.X.; Cheng, Z.; Landry, D.W.; Kontula, K.; Swan, H.; Marks, A.R. Sudden death in familial polymorphic ventricular tachycardia associated with calcium release channel (ryanodine receptor) leak. Circulation 2004, 109, 3208-3214. [CrossRef] [PubMed]

163. Refaat, M.M.; Hassanieh, S.; Scheinman, M. Catecholaminergic polymorphic ventricular tachycardia. Card. Electrophysiol. Clin. 2016, 8, 233-237. [CrossRef] [PubMed]

164. Terentyev, D.; Nori, A.; Santoro, M.; Viatchenko-Karpinski, S.; Kubalova, Z.; Gyorke, I.; Terentyeva, R.; Vedamoorthyrao, S.; Blom, N.A.; Valle, G.; et al. Abnormal interactions of calsequestrin with the ryanodine receptor calcium release channel complex linked to exercise-induced sudden cardiac death. Circ. Res. 2006, 98, 1151-1158. [CrossRef] [PubMed]

165. Priori, S.G.; Napolitano, C. Cardiac and skeletal muscle disorders caused by mutations in the intracellular $\mathrm{Ca}^{2+}$ release channels. J. Clin. Investig. 2005, 115, 2033-2038. [CrossRef] [PubMed]

166. Postma, A.V.; Denjoy, I.; Kamblock, J.; Alders, M.; Lupoglazoff, J.M.; Vaksmann, G.; Dubosq-Bidot, L.; Sebillon, P.; Mannens, M.M.; Guicheney, P.; et al. Catecholaminergic polymorphic ventricular tachycardia: Ryr2 mutations, bradycardia, and follow up of the patients. J. Med. Genet. 2005, 42, 863-870. [CrossRef] [PubMed]

167. Aizawa, Y.; Komura, S.; Okada, S.; Chinushi, M.; Morita, H.; Ohe, T. Distinct U wave changes in patients with catecholaminergic polymorphic ventricular tachycardia (CPVT). Int. Heart J. 2006, 47, 381-389. [CrossRef] [PubMed]

168. Refaat, M.M.; Hotait, M.; Tseng, Z.H. Utility of the exercise electrocardiogram testing in sudden cardiac death risk stratification. Ann. Noninvasive Electrocardiol. 2014, 19, 311-318. [CrossRef] [PubMed]

169. Napolitano, C.; Priori, S.G.; Bloise, R. Catecholaminergic polymorphic ventricular tachycardia. In GeneReviews ${ }^{\circledR}$; Pagon, R.A., Adam, M.P., Ardinger, H.H., Wallace, S.E., Amemiya, A., Bean, L.J.H., Bird, T.D., Ledbetter, N., Mefford, H.C., Smith, R.J.H., et al., Eds.; University of Washington: Seattle, WA, USA, 1993.

170. Liu, N.; Ruan, Y.; Priori, S.G. Catecholaminergic polymorphic ventricular tachycardia. Prog. Cardiovasc. Dis. 2008, 51, 23-30. [CrossRef] [PubMed]

171. Priori, S.G.; Napolitano, C.; Tiso, N.; Memmi, M.; Vignati, G.; Bloise, R.; Sorrentino, V.; Danieli, G.A. Mutations in the cardiac ryanodine receptor gene (HRYR2) underlie catecholaminergic polymorphic ventricular tachycardia. Circulation 2001, 103, 196-200. [CrossRef] [PubMed] 
172. Lahat, H.; Pras, E.; Olender, T.; Avidan, N.; Ben-Asher, E.; Man, O.; Levy-Nissenbaum, E.; Khoury, A.; Lorber, A.; Goldman, B.; et al. A missense mutation in a highly conserved region of CASQ2 is associated with autosomal recessive catecholamine-induced polymorphic ventricular tachycardia in bedouin families from israel. Am. J. Hum. Genet. 2001, 69, 1378-1384. [CrossRef] [PubMed]

173. Postma, A.V.; Denjoy, I.; Hoorntje, T.M.; Lupoglazoff, J.M.; Da Costa, A.; Sebillon, P.; Mannens, M.M.; Wilde, A.A.; Guicheney, P. Absence of calsequestrin 2 causes severe forms of catecholaminergic polymorphic ventricular tachycardia. Circ. Res. 2002, 91, e21-e26. [CrossRef] [PubMed]

174. Sumitomo, N. Current topics in catecholaminergic polymorphic ventricular tachycardia. J. Arrhythm. 2016, 32, 344-351. [CrossRef] [PubMed]

175. Nyegaard, M.; Overgaard, M.T.; Sondergaard, M.T.; Vranas, M.; Behr, E.R.; Hildebrandt, L.L.; Lund, J.; Hedley, P.L.; Camm, A.J.; Wettrell, G.; et al. Mutations in calmodulin cause ventricular tachycardia and sudden cardiac death. Am. J. Hum. Genet. 2012, 91, 703-712. [CrossRef] [PubMed]

176. Gomez-Hurtado, N.; Boczek, N.J.; Kryshtal, D.O.; Johnson, C.N.; Sun, J.; Nitu, F.R.; Cornea, R.L.; Chazin, W.J.; Calvert, M.L.; Tester, D.J.; et al. Novel CPVT-associated calmodulin mutation in CALM3 (CALM3-A103V) activates arrhythmogenic ca waves and sparks. Circ. Arrhythm. Electrophysiol. 2016. [CrossRef] [PubMed]

177. Roux-Buisson, N.; Cacheux, M.; Fourest-Lieuvin, A.; Fauconnier, J.; Brocard, J.; Denjoy, I.; Durand, P.; Guicheney, P.; Kyndt, F.; Leenhardt, A.; et al. Absence of triadin, a protein of the calcium release complex, is responsible for cardiac arrhythmia with sudden death in human. Hum. Mol. Genet. 2012, 21, 2759-2767. [PubMed]

178. Vega, A.L.; Tester, D.J.; Ackerman, M.J.; Makielski, J.C. Protein kinase a-dependent biophysical phenotype for V227F-KCNJ2 mutation in catecholaminergic polymorphic ventricular tachycardia. Circ. Arrhythm. Electrophysiol. 2009, 2, 540-547. [CrossRef] [PubMed]

179. Mohler, P.J.; Splawski, I.; Napolitano, C.; Bottelli, G.; Sharpe, L.; Timothy, K.; Priori, S.G.; Keating, M.T.; Bennett, V. A cardiac arrhythmia syndrome caused by loss of ankyrin-b function. Proc. Natl. Acad. Sci. USA 2004, 101, 9137-9142. [CrossRef] [PubMed]

180. Bhuiyan, Z.A.; Hamdan, M.A.; Shamsi, E.T.; Postma, A.V.; Mannens, M.M.; Wilde, A.A.; Al-Gazali, L. A novel early onset lethal form of catecholaminergic polymorphic ventricular tachycardia maps to chromosome 7p14-p22. J. Cardiovasc. Electrophysiol. 2007, 18, 1060-1066. [CrossRef] [PubMed]

(C) 2017 by the authors; licensee MDPI, Basel, Switzerland. This article is an open access article distributed under the terms and conditions of the Creative Commons Attribution (CC BY) license (http:/ / creativecommons.org/licenses/by/4.0/). 